\title{
EL ANÁLISIS LINGÜÍSTICO DESDE UN ENFOQUE PRAGMÁTICO
}

\author{
Catalina Fuentes Rodríguez \\ Universidad de Sevilla. \\ Grupo de Investigación "Argumentación y Persuasión en Lingüística" \\ cfuentes@us.es
}

\begin{abstract}
Resumen
Tras las investigaciones de los últimos años en que han aparecido distintas propuestas pragmáticas, se plantea la necesidad de una metodología única para la Lingüística. En el presente estudio se presenta una propuesta modular de Linguística Pragmática que sirva de modelo global para toda manifestación discursiva. En ella se integran aspectos intralingüísticos y contextuales, que se influyen mutuamente. La rentabilidad de dicho modelo se demuestra con casos prácticos del nivel palabra, enunciado y texto.

PALABRAS CLAVE: pragmática, lingüística, metodología.
\end{abstract}

\begin{abstract}
Since the latest researches on pragmatics, we need one methodology for all the linguistics. In this work we present a modular proposal of Pragmatic Linguistics. This will be a global model for every discourse. The formal units interact with both the context and the situation. We show the explanatory ability of this model with instances from the word, sentence and text level.
\end{abstract}

KEY WORDS: pragmatics, linguistics, methodology.

\section{La Lingüística pragmática: propuesta de un modelo}

La investigación pragmática, hasta hace poco, se consideraba externa a la Lingüística. Sin embargo, hoy está integrada en ella y es un tema obligado en todo congreso o estudio. La insuficiencia de las grandes metodologías del s. XX para describir la lengua oral o los niveles marginales de la oración ha llevado a la necesidad de tener en cuenta todos los factores que rodean al objeto lingüístico en su producción. Han proliferado los acercamientos desde diversos aspectos del entorno social, hasta crear una base teórica, un conjunto de conocimientos en los que hay unas constantes, unas ideas básicas que todos comparten.

En mi caso, el abordar el estudio de los "enlaces extraoracionales" (como los llamaba Gili Gaya, 1972) me llevó a buscar metodologías que pudieran explicar el funcionamiento más allá de la oración, y, así, utilicé instrumentos provenientes de la Lingüística de la enunciación, la Lingüística del texto, la Teoría de la argumentación 
o la Pragmática. A partir de ahí, mi acercamiento a los distintos temas gramaticales o discursivos ha tenido en cuenta todos los participantes en el evento comunicativo. Del mismo modo, las investigaciones sobre marcadores, modalidad, funciones o usos discursivos han crecido bastante y llenan nuestro panorama bibliográfico. Ante esto cabe hacer balance y plantearse si ya contamos con una nueva metodología de trabajo. Esta pregunta es difícil de responder, ya que generalmente, aunque se integra lo pragmático, o se acepta, mejor dicho, esto no llega a constituir, sin embargo, un paradigma único, ni una metodología aplicable a todos los fenómenos, por varias razones:

a) los estudios son parciales: hay muchos trabajos sobre conectores, elementos modales, lengua oral, pero de manera atomista, sin un modelo integrador

b) hay muchos modelos teóricos, también parciales, sin una unidad ni punto en común, ni capacidad explicativa para toda la lengua

c) se establece una separación tajante entre gramática y pragmática, entre código y uso. Se analiza como gramatical todo lo que pertenece a la sintaxis oracional, y como pragmático los "valores o comportamientos discursivos", en suma, el significado contextual. La semántica se aplica generalmente a las lexías y al contenido designativo referencial, y la pragmática se encarga de los valores connotativos, los "efectos de sentido". Se considera la pragmática, así, por parte de muchísimos autores, como una parcela de la gramática, o como una alternativa a ella. Es frecuente encontrar análisis que tras describir un elemento desde el punto de vista gramatical o sintáctico, pasan a sus "empleos pragmáticos". O bien oponen funciones gramaticales a discursivas: piensan que hablar del valor que tienen, por ejemplo, unos elementos como cierre en la interacción pertenece a los "usos discursivos o pragmáticos" y no a su gramática. Consideran gramatical lo abstracto, lo oracional, y pragmático lo discursivo: el uso contextual y lo supraoracional. Otros lo consideran una parte del significado, una contrapartida a la semántica. Pero entonces cabría preguntar ¿no hay fonética pragmática ni sintaxis pragmática? ¿Dónde están los valores "discursivos", corteses, etc de la entonación? ¿Son sólo efectos de sentido? ¿Cómo se integra esto en un diseño científico global? ¿En qué consisten las funciones "discursivas" o "pragmáticas" de los conectores o de los diferentes esquemas sintácticos? Si la gramática termina en la oración, ¿no hay estructura abstracta más allá de ella? ¿Cómo sistematizar los "valores discursivos o pragmáticos”? ¿Son asistemáticos? La pragmática quedaría fuera de la ciencia, en el plano interpretativo, subjetivo, pues.

Las incoherencias, como vemos, son muchas, pero ni siquiera se plantean, ya que es más cómodo para el investigador tomar lo pragmático como un añadido, y no variar su perspectiva de trabajo. En el fondo, no se cambia de metodología, no se cambia de enfoque, sólo se añade un apartado más, sin detenerse a pensar en lo que esto supone. 
Fuera de España, la dinámica es otra, pero no deja de ser atomista. Generalmente consiste en la aplicación de teorías particulares que se presentan como modelos globales. Es decir, se estudia un fenómeno desde la teoría de la pertinencia, la teoría de la argumentación, o la lingüística cognitiva, pero de forma también aislada, sin trascender a la metateoría, y sin plantearse si esos métodos son explicativos de toda la lengua, o tienen una relevancia parcial. Si se analiza, por ejemplo, los usos discursivos de un adverbio o de un morfema nominal como el diminutivo, no se llega a trascender el caso concreto y no se analiza si esto supone que los morfemas tienen que ser estudiados desde su rendimiento modal o argumentativo. $\mathrm{O}$ si las clases de palabras deben definirse no sólo en cuanto a su contribución al esquema oracional estándar, sino en sus valores expresivos en los diferentes dominios. Tampoco se plantea si analizar los valores argumentativos de una construcción debe implicar un cambio en nuestra visión del resto de fenómenos lingüísticos. Si estudiamos "efectos pragmáticos" debemos reflexionar sobre qué metodología de trabajo estamos empleando y si esto tiene una trascendencia en el planteamiento global.

Sólo autores como Roulet o Adam $^{1}$ han visto la necesidad de contar con un modelo general, una nueva Lingüística que explique los textos orales y los escritos, los publicitarios junto a políticos, literarios, etc... y todo teniendo en cuenta tanto el código, lo microestructual, como las dimensiones que surgen en la enunciación y que se manifiestan en los niveles superiores a la oración.

Como hemos defendido en otros trabajos (Fuentes, 1997, 2000), para nosotros la pragmática es un enfoque, una manera de hacer Lingüística, que se opone al estudio abstracto, aislado del contexto. La Lingüística pragmática es un estudio integral e integrado de los fenómenos lingüísticos en su contexto, contemplando la interacción entre características microestructurales y macroestructurales o dependientes de la situación. Es necesario cambiar la forma de acercarse al estudio lingüístico, y, seamos especialistas en fonética, en semántica o en sintaxis, trabajemos sobre conversaciones o sobre textos escritos, debemos tener en cuenta siempre la necesidad de explicar el uso de los mecanismos lingüísticos, desde su empleo en el contexto comunicativo. Debemos realizar una descripción desde todas las caras que tiene este prisma. No podemos seguir manteniendo la visión plana y lineal que ha dominado hasta ahora la investigación. La realidad es más rica y, por tanto, nuestra investigación, si quiere ser seria y valiosa, debe contemplarlas todas.

Es cierto que esto supone un gran esfuerzo, porque resulta difícil descubrir la interrelación entre los fenómenos. Es necesario antes conocer el funcionamiento de todas estas parcelas. Es decir, necesitamos conocer la influencia de la enunciación en el mensaje, de la subjetividad del hablante, de sus fines persuasivos, del nivel de relevancia o pertinencia de una información en el contexto en que se produce, de la adecuación o no al mismo. ...Todo esto tiene sus medios de expresión y sus estructuras perfectamente codificadas. Pero este trabajo está por hacer. Necesitamos

1 Cfr. Roulet (1991a y b, 1997, 2000), Adam (1990), y Fuentes (2000). 
disponer de inventarios de unidades con su descripción pragmafuncional. Al mismo tiempo, tenemos que admitir la riqueza de la información que nos transmiten los mensajes lingüísticos, que no son lineales, ni de una sola cara, sino que están llenos de contenido y de matices, ordenados en una jerarquía de relevancia o predominio. Es decir, nuestra visión del fenómeno lingüístico debe ser multidimensional, como multidimensional es la realidad y la comunicación. Nos olvidamos de la razón de ser de la lengua: es un vehículo de comunicación humana, entre seres temporales sujetos a muchas variaciones.

El cambio, pues, es bastante profundo. No se trata de añadir componentes al estudio lingüístico, sino redefinirlo todo:

a) Extender el número de unidades hasta el texto.

b) Describirlas desde una vertiente paradigmática como inventarios y a la vez por su comportamiento sintagmático, entendiendo esto en el sentido más amplio posible: no solo teniendo en cuenta el cotexto lingüístico, el resto de unidades que comparten la enunciación, sino también el entorno social, histórico, práctico o cultural.

c) Analizarlo todo desde la producción, desde la realización concreta, partiendo de una realidad básica: en esa comunicación todos los factores están interrelacionados y todas las informaciones también.

Por tanto, la caracterización de una unidad o construcción comprende multitud de aspectos que se potencian mutuamente, algunos de los cuales son más rentables que otros, están en una relación de predominio o preferencia.

Por ejemplo, en el enunciado siguiente

Obsesionado por ver de nuevo a Tutankamón, Jonet iba constantemente a los jardines de la Casa Dorada con la intención de sorprenderle en un baño furtivo (Crea, T. Moix: El arpista ciego, Barcelona, Planeta, 2002).

"obsesionado por ver de nuevo a Tutankamón" es una estructura de participio que modifica a "Jonet". Funcionalmente actuaría como adyacente de este sustantivo, una construcción que adopta un valor adjetivo, como lo es propiamente el participio. Ahora bien, su disposición entre pausas, con cierto valor explicativo, ha hecho que algunos lo hayan considerado cercano al adjetivo incidental de Lapesa (1975), y a la función incidental de Fernández (1993) y Martínez (1994), una construcción que añade una predicación secundaria. Es decir, tendríamos todo un núcleo predicativo que actuaría con un valor de condicionante causal de lo dicho en la principal: "La razón de ir a los jardines de la Casa Dorada es la obsesión de Jonet". Esto podría resolverse si admitimos una función de circunstante causal, tal como ha planteado Gutiérrez Ordóñez (1997): una predicación secundaria, en primera posición, entre pausas, que afecta a toda la principal. 
¿Implicaría esto dejar de considerarlo una construcción de participio? En absoluto, porque su estructura no impide, por el contrario lo explica, su comportamiento significativo como predicación causal con respecto al principal. La función de circunstante está en el plano del enunciado, supone una forma de manifestación ostensiva de un complemento, cuya incidencia no afecta sólo al sustantivo sujeto ("Jonet", en este caso), sino que trasciende a toda la predicación oracional. Para eso el hablante se detiene a marcarlo con una pausa. En este caso el empleo discursivo, la necesidad de indicar funcionamientos que afectan a bloques sintáctico-semánticos se concreta en el empleo de estructuras sintácticas periféricas en la oración. La sintaxis y la entonación se ponen al servicio de la intención comunicativa del hablante y los diferentes niveles de inserción.

Pasemos ahora a un plano más externo, de intervención del contexto social ${ }^{2}$, que afecta a la lexicosemántica: Estudiar los insultos, formas fundamentalmente descorteses, como medios de afiliación entre miembros de un grupo social (así la llamada anticortesía de Zimmerman, 2003, cuando los jóvenes los usan como marcas de empatía entre los componentes de la pandilla) no es anular el contenido de interdicción, sólo ponerlo en un segundo plano: "No seas cabrón..." no actúa como una forma de atacar al otro, en una situación interactiva de confianza con los interlocutores, y, además, esto no anula el valor "inadecuado" que lleva asociado. Al contrario, se usa como medio de conexión produciendo una inversión significativa: de lo más extremo en el polo negativo, a lo más extremo en el polo positivo, precisamente por entrar en juego todos estos factores.

Consecuencia inmediata de este enfoque es admitir:

(1) Que el contexto social puede variar el valor de las unidades estudiadas, ya que el hablante puede atenuar, enfatizar sus valores o realizar una inversión de sus efectos. Todo depende siempre de la intención comunicativa del locutor.

(2) Que tenemos que tener en cuenta contenidos diferentes a los considerados hasta ahora.

(3) Que en la definición de una unidad intervienen muchos factores, y no todos en el mismo grado de relevancia. Tenemos que tener una visión prototípica de las categorías y realizar una caracterización donde las dimensiones están en una relación de predominio: unas están en un primer plano y otras pertenecen al fondo (López, 1994), a los valores acompañantes o secundarios. Ahora bien, un valor secundario puede ver, como en a), potenciado o invertido su valor por la acción del contexto.

Por ello, es fundamental que contemos con un esquema de trabajo, que nos sirva de guía en la investigación. No olvidemos que en este acercamiento pragmático a

2 Este trabajo se inscribe dentro del Proyecto de Excelencia de la Junta de Andalucía (HUM 593)

"La violencia verbal y sus consecuencias sociales". 
la Lingüística no disponemos de un paradigma de estudios previos, y necesitamos sentar las bases del comportamiento comunicativo, es decir, de lo que es en sí "la lengua en contexto", para poder definirla desde todos los rincones y poder acceder a la realidad de su funcionamiento. Para ello proponemos un modelo, en línea con lo que otros investigadores, como Adam o Roulet, han propuesto. En todos los intentos se llega a la misma conclusión: en un enfoque global hay que usar una perspectiva modular, donde todos los componentes interactúan, no son compartimentos estancos. Nuestro modelo ha intentado aunar todo lo que nos ha parecido rentable para una lengua como el español y cuyo rendimiento hemos comprobado en la práctica. Queremos decir con esto que hemos llegado a esta propuesta tras muchos años de estudios concretos sobre estructuras extraoracionales, tras la comprobación de su rentabilidad en los estudios parciales. Al mismo tiempo, este modelo actúa de marco de estudio para conseguir en un futuro una descripción pragmática del español, lo que sería una gramática comunicativa. Las distintas parcelas que en él se incluyen actúan como programas de trabajo que nos están exigiendo su desarrollo: ver qué unidades cubren la dimensión argumentativa, la informativa o la modal.

En 2000 presentamos este modelo de Lingüística pragmática, que llamamos así porque queremos resaltar que nuestro interés es proporcionar un método de análisis lingüístico, comparable en rigor a cualquier otra metodología, ya sea tradicional, estructural o generativa. La novedad es su perspectiva de estudio: se analiza toda la lengua pero teniendo en cuenta el uso, la producción, y no el mensaje acabado como producto, sin huellas de su realización. Para ello, tras muchas investigaciones que han refrendado su operatividad, hemos partido del contexto natural del estudio lingüístico: el esquema comunicativo. Es ahí donde cobran sentido todos los elementos, la razón de ser de una lengua. Hablante, oyente, contexto histórico, cultural, interconexión entre individuos... cobran relevancia y se manifiestan en cada elección lingüística.

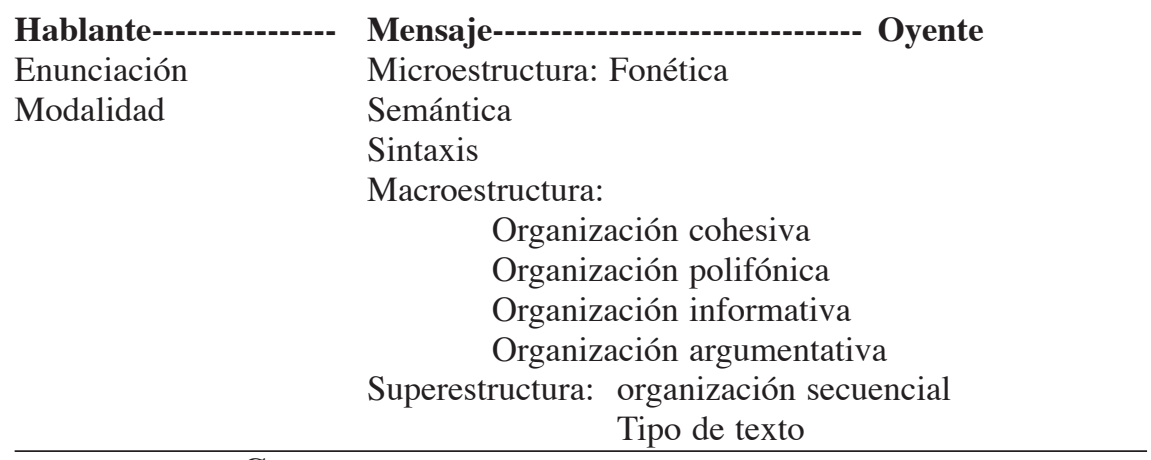

\section{Contexto}

En este modelo se integran los aspectos más puramente lingüísticos, o considerados tradicionalmente así (la llamada microestructura fonética, sintáctica o semántica), con otros campos que atienden a dimensiones superiores del texto: la 
superestructura o tipo textual, la organización macroestructural del texto en párrafos, secuencias,... y los aspectos derivados de la organización informativa y argumentativa del mismo. Asimismo, el hablante deja su marca en el enunciado en dos aspectos: el enunciativo (acto de habla) y modal (fuerza ilocutiva). Como vemos, todos los aspectos de la Linguística textual, la Teoría de la argumentación (Anscombre-Ducrot, 1994), la Teoría de la enunciación (Ducrot, 1984), los actos de habla de Austin (1978) y Searle (1980) y la Teoría de la relevancia de Sperber-Wilson (1986), o la perspectiva etnometodológica, han ido descubriéndonos dimensiones del estudio del texto, que hemos aunado aquí. Solas, nos descubren una parcela del mensaje. Juntas e interactuando, imbricándose, nos hacen ver toda la riqueza del texto y toda la amplitud que el estudio pragmático debe considerar.

Esta metodología ha sido aplicada en nuestros trabajos y los de nuestros alumnos, y hemos comprobado su rentabilidad. Por ello queremos exponer su funcionamiento con casos concretos, para, así, poder mostrar claramente sus virtudes analíticas, su potencialidad. Este método nos permite explicar muchos cambios en el discurso.

\section{Nivel palabra}

2.1. Comenzamos con el nivel más accesible para el análisis, porque en él el objeto de estudio está acotado y es más fácilmente observable. De ahí que sea el más tratado. En este campo ha tenido un gran desarrollo el estudio de los conectores, también llamados "marcadores del discurso"3. Estas unidades han sido descritas teniendo en cuenta sus valores sintácticos, sus "empleos discursivos" o valores procedimentales. Se ha utilizado la teoría gramatical al uso, la teoría de la argumentación o la teoría de la relevancia ${ }^{4}$. Algunos han trabajado desde una perspectiva enunciativa o argumentativa, pero ninguna de estas aportaciones constituyen un estudio global en el que se haga algo más que unir las características llamadas tradicionalmente gramaticales a los usos discursivos. Es más, ninguno de ellos se ha planteado que una unidad modal o enunciativa, o un conector tenga más valores que los que provienen de esa clasificación. Es decir, si el elemento es modal, se describe desde este punto de vista. Si lo hemos clasificado como enunciativo, explicamos su aportación significativa al ámbito del decir. Si el conector es considerado argumentativo, se analiza su aportación a la estructura argumento-conclusión. Pero no se le añaden características de los otros planos. No se contempla la posibilidad de que un conector tenga, además, un valor modal, o enunciativo, como de hecho ocurre. O si, aparte de marcar la subjetividad o fuerza ilocutiva, un operador funciona en el plano ar-

3 Término inadecuado en nuestra opinión, porque vuelve a crear otro cajón de sastre, y precisamente los estudios pragmáticos intentan abordar todos los comportamientos discursivos que nos permiten diferenciar las unidades y sus diferentes funciones. Cfr. Fuentes (2001). Sobre este tema véase Fuentes (1987, 1993, 1996a y b, 2009a), Martín Zorraquino-Portolés (1999), Martín Zorraquino-Montolío (1998), Portolés (1998), Montolío (2002), entre otros.

4 Vid. las distintas aportaciones recogidas en Martín Zorraquino-Montolío (eds., 1998). 
gumentativo, o sirve como instrumento de focalización informativa o tematización. Es decir, partimos de una visión plana, lineal, con compartimentos estancos, en pos del rigor. Pero tal rigor no se lleva a efecto, debido a que en el plano discursivo todos los aspectos están interrelacionados, y estas dimensiones son eso: aspectos del comportamiento, que deben verse modularmente.

Este es el enfoque que defendemos y que se ha concretado en la metodología que seguimos en nuestro Diccionario de conectores y operadores del español ${ }^{5}$. Es también su novedad. En él hemos pretendido recoger todas las unidades que actúan supraoracionalmente, ya sea como mecanismos relacionantes de enunciados (conectores) o aquellos elementos que actúan dentro de él marcando argumentación, enunciación, modalidad o información ${ }^{6}$. Es decir, los operadores de cada uno de los componentes de nuestro modelo pragmático. Significa esto que los módulos presentados disponen de un paradigma en español de unidades y de estructuras, lo que refuerza el diseño. Con esta distinción entre operadores y conectores queremos, además, reafirmar la existencia de funciones sintácticas puramente discursivas, que deben unirse a las tradicionalmente manejadas en la sintaxis oracional.

Hemos incluido en el análisis tanto la descripción microestructural, con todos los factores que intervienen y definen sus características sintácticas (posición, movilidad en la oración, distribución, combinación con otros elementos) como entonativas. Y esto se integra con los valores que pueden tener en el plano modal, enunciativo, informativo y argumentativo. Todas las unidades, pertenezcan al campo que sea, pueden desarrollar un comportamiento específico en los demás, ya que estas dimensiones son simultáneas, no excluyentes entre sí. El texto es un entramado complejo con interconexiones constantes. Además, se completa con el tipo de discurso en que aparecen y el nivel de lengua: si son orales, escritos, coloquiales o cultos, o ambos. Todos estos aspectos se influyen mutuamente. Así, descubriremos constantes sintácticas o entonativas que sirven para diferenciar conectores de operadores, o para definir unos operadores frente a otros. Por ejemplo, la posibilidad que tienen los modales de formar enunciado de respuestas o conectar con la oración a través de que, frente a los enunciativos.

$-i$ Se acuerda de Noia?

- Claro. Cuando puedo me escapo (Crea, La Voz de Galicia, 15-1-2004).

5 El proyecto "Diccionario de conectores y operadores del español" fue financiado por la DGICyT desde 2002-2005, aunque no se terminó en esas fechas. La parte relativa a conectores y operadores acaba de publicarse (Fuentes, 2009a), y la parte correspondiente a interjecciones (que hace E. Alcaide) saldrá posteriormente. Presentamos avances de los resultados obtenidos en las Jornadas sobre "El análisis del discurso: partículas, modalidad y conexión" de Zaragoza (2005a, e.p.), en el Congreso de la Sociedad Española de Lingüística de 2007, y en el seminario "Gramática, Semántica, Pragmática y Diccionarios”, organizado por al Dra. Garcés en la Univ. Carlos III de Madrid, en octubre de 2008. Parte de sus frutos han ido apareciendo en artículos: puede consultarse Fuentes (2006a y c, 2005a, 2006a, 2007b, 2008).

6 Para la diferencia conector/operador vid Fuentes (2003). 
Claro se usa como elemento de respuesta confirmativa, solo o acompañado de sí, no. A veces va unido al enunciado o respuesta a través de que:

¿Cómo es eso de que tiene más cuerpo que tú?, queremos saber. Claro que sí, y el asunto es que se mete en mi clóset para resolver cuando no desea ponerse lo suyo (Crea, Vea on Line, 1761, 11-5-2003).

Lo encontramos en otros elementos reafirmativos:

¿Les ha divertido vestirse como lo hacían en el siglo XIX? Por supuesto (TP 1963, 11-2003)

¿El uso político que les da SL a las cárceles se fortaleció cuando Montesinos le dio insumos a Guzmán para redactar manifiestos y acceder a publicaciones?

- Por supuesto que sí (Crea, La República, 25-11-2004)

- ¿Monterroso toma en serio esta conversación y a este interlocutor?

- Desde luego (Crea, A. Monterroso: Literatura y vida, Madrid, Alfaguara, 2004)

Conocemos bien a Dalí como pintor, y pocos dudan ya de que poseyó un talento envidiable como escritor o como diseñador, pero ¿podemos hablar de él como 'arquitecto'? Desde luego que sí: el interés de Dalí por la arquitectura no fue ocasional o pasajero, pues perfora toda su carrera, desde algunas acuarelas de 1922 hasta los últimos años de su vida (Crea, El País, Babelia, 24-4-2004).

Los elementos enunciativos: francamente, sinceramente, la verdad, ... no podrían ir unidos con que.

Cierto que podría haber estado más sutil y hablado Sí. Sí, la verdad (Crea, La venganza será terrible, Radio Continental, 11-12-1998).

Este, sin embargo, podría aparecer unido con es que: la verdad es que..., en una estructura de enfatización:

Técnicamente hablando, la distancia focal de un objetivo es la medida en milímetros desde el centro óptico del conjunto de lentes que la forman a la película (por eso, en términos generales, a más distancia focal más grandes son) aunque esto la verdad es que nos importa bastante poco a la hora de su utilización. (Crea, Aquanet. Revista virtual de buceo, $\mathrm{n}^{\circ} 35,05 / 2002$ ).

Todos los modales confirmativos (claro, por supuesto, desde luego, naturalmente...) establecen un énfasis en la aserción y pueden confirmar algo previo. Al mismo tiempo presuponen la existencia de otros enunciadores ${ }^{7}$ que comparten lo dicho,

7 Enunciador es el que asume la responsabilidad de lo dicho. Cfr. Ducrot (1984) o Fuentes (1995). 
con lo cual respaldan la opinión del hablante, que de este modo se ve aliviado en la responsabilidad enunciativa. Este hecho explica que pueda usarse en un proceso más avanzado de gramaticalización como mero apoyo, afirmativo, de lo dicho por el hablante. Él mismo le da fuerza a su aserción y lo hace de forma metódica, como continuativo, elemento de apoyo mientras construye su comunicación.

Sí, bueno, es muy difícil hacer eso porque, claro, las palabras en sí mismas separadas de la de otras palabras poco dicen, ¿no? Todas las palabras son bellas, todas en son bellas también (Crea, Hoy por hoy, Cadena Ser, 24-4-1999).

Esto es menos frecuente con desde luego o por supuesto, ya que estos elementos tienen una carga reafirmativa más fuerte que claro.

Por supuesto, no pretendemos reflejar lo mucho que representa el cine español en estos tres spots, sino hacer un llamamiento al espectador para proteger y defender nuestras películas, que tienen que ocupar un espacio mayor del que tienen en la actualidad (Crea, La Voz de Galicia, 15-1-2004).

Cuando sí lo encontramos casi como continuativo es en el empleo repetido en el lenguaje parlamentario, en los discursos de los políticos, que lo utilizan como estrategia de fuerza argumentativa, como elemento de imposición, pero que con el tiempo llega a perder dicho valor y se adelgaza su contenido quedándose como mera estrategia formal: como un medio de brillantez discursiva. Un paso del contenido a la forma, $\mathrm{o}$, si se quiere, de la fuerza ilocutiva (subjetividad) a la fuerza locutiva (el decir).

Continuaremos creciendo a buen ritmo, creando empleo de forma significativa y además la situación patrimonial de las familias es buena. Algunas personas se refieren a ella única y exclusivamente desde la perspectiva de la deuda, pero desde luego olvidan también el elevado efecto riqueza que se ha producido, y como consecuencia de ello la comparación es una comparación positiva para la mayor parte de las familias españolas. Por tanto, el año 2008 seguirá siendo un año de crecimiento, de creación de empleo, de funcionamiento de una economía con flexibilidad y con tipos bajos, en la que se favorecerá el mantenimiento de la actividad económica. Desde nuestro diagnóstico, las previsiones del Gobierno son razonables y desde luego creemos que en el año 2008 no habrá un proceso de destrucción de empleo sino todo lo contrario, seguirá aumentando la ocupación. (Sr. Fernández Marugán, PSOE. Diario de Sesiones del Parlamento Español, 310, 20-12-2007).

Este análisis también nos revela cómo los elementos modales o enunciativos tienen un efecto de enfatización informativa del enunciado en que aparecen. En este campo, pues, no sólo hay operadores específicos que marcan la focalización o la tematización, sino también otros que lo hacen como efecto añadido a su función primaria. 
Insertar en el análisis una perspectiva pragmática significa poder explicar todas las formas, y encontrarles su verdadero valor. De manera que variante no implica elección libre, sin aportación significativa. Por el contrario, una descripción mucho más minuciosa debe indicar para cada una su contexto de empleo, los diferentes factores que entran en juego en el cotexto y en el contexto comunicativo para que eso se produzca.

El concepto de variación es pragmático, pero con la pragmática se consigue describir y no debe plantearse como una enumeración de posibilidades sin ninguna precisión de empleo.

En este diccionario hemos encontrado toda una serie de unidades cuyo comportamiento trasciende los límites que la gramática se había autoimpuesto. Nos ha permitido descubrir y describir paradigmas de unidades, comportamientos discursivos que trascienden la oración y apuntan al hablante, al oyente y a otros límites textuales. Al mismo tiempo, nos ha permitido conocer muchas constantes o tendencias de empleo ligadas sobre todo al problema de la gramaticalización. Así, por ejemplo, los límites entre unidades, que, como hemos dicho, no son en absoluto fronteras fijas, sino borrosas, permeables. Veámoslo en algunas unidades.

\subsection{FRANCAMENTE 1 .}

\section{Operador enunciativo}

1. Califica al decir y al hablante, que se muestra sin reservas en su acto de hablar.

2. Funciona como modificador enunciativo de todo el enunciado. El hablante califica su actitud como sincera con el receptor. La comunicación es directa, sin reservas:

No puedo entender, francamente, por qué ha tomado tanto tiempo decidir si hay jurisdicción federal y el mandamus. (El Nuevo Día, 14-12-2004). 3. Afecta a todo el enunciado, o se focaliza sobre un segmento. En este caso aparece intercalado o en posición final, posponiéndose al elemento sobre el que recae el comentario enunciativo:

Es un problema creciente y francamente no sé cuál es la mejor manera de frenarlo (Fotogramas 1921, 11-2003)// Sobre Bello los juicios de Lastarria se mueven en una constante pendular: los hay ponderados, pero también varios, francamente, polémicos; leyéndolos uno se da cuenta por qué Miguel Luis Amunátegui se sintió en el deber de intervenir (Bicentenario. Revista de Historia de Chile y América, 1, 1, 2002).

\section{ORIGEN}

Adverbio de modo con el valor de de manera franca, sincera.

\section{POSICIÓN. ENTONACIÓN}

Inicial, intercalado o final, entre pausas.// Forma grupo entonativo independiente. 


\section{COMPORTAMIENTO EN EL PLANO MODAL Y ENUNCIATIVO}

Es una marca directa de la implicación personal del hablante en lo dicho. Su actitud es sincera, sin ambages.

\section{TIPOS DE TEXTO}

conv.// cul //or_es.//.8 (Fuentes: 2009a, págs. 176-177).

Francamente es un operador enunciativo. Actúa en el enunciado marcando la actitud de sinceridad o franqueza que el hablante quiere mostrar con respecto a su discurso. Para ello, como comprobamos, adopta una distribución específica: se coloca entre pausas, formando un grupo entonativo independiente y afectando a todo el enunciado. Tiene movilidad dentro de él, y es una muestra clara de imposición del hablante. En respuesta no aparece solo, sino acompañando a sí, no. Pero tiene otro uso en que se integra en el enunciado, no se aísla, no va entre pausas, y afecta a un segmento. En este último caso actúa como operador argumentativo. Es decir, el cambio de distribución sintáctica supone un cambio de tipo de elemento: pasa de lo enunciativo a lo argumentativo. Actúa como intensificador, poniendo de relieve la información de un elemento y marcando su fuerza, pero sin perder esa clara implicación del hablante. Ahora pertenece al plano de la argumentación, pero eso no obsta para que siga manteniendo un valor enunciativo. La franqueza como actitud del hablante queda en un segundo plano, pero coexiste con la intensificación. Como vemos, los aspectos sintácticos más intraoracionales se mezclan con lo informativo, lo argumentativo y lo enunciativo, todo a la vez, interactuando. Este es el comportamiento específico de las unidades supraoracionales. El ámbito del enunciado y el discurso tiene sus propias claves, instrumentos y funciones, y hay que abordarlos desde esa perspectiva.

Asimismo, esta unidad nos sirve para ilustrar una tendencia observada en el estudio de estos operadores: es muy frecuente que elementos pertenecientes al plano modal o enunciativo desarrollen un segundo empleo como intensificadores del adjetivo, como operadores pragmáticos. En este caso, a la fuerza argumentativa añaden el comentario sobre la actitud modal o enunciativa del hablante. Lo vemos también en: maravillosamente, asombrosamente, verdaderamente... 9 . Esto significa que el hablante para intensificar acude a elementos de enunciación o modalidad, no sólo a argumentativos o cuantificadores. El ámbito supraoracional es una zona de límites permeables entre todos sus ámbitos.

8 Conv: conversacional, cul: culto, or_es: oral-escrito. Otras abreviaturas: t-tex: todo tipo de texto, or: oral, escr: escrito, colo: coloquial, col_cu: coloquial y culto.

9 En cuanto a las cuatro horas que tardó el jurado en deliberar, De la Concha explicó que se debía a que la lista de candidatos era "verdaderamente importante". (La Voz de Galicia, 13-12-2000). Vid. Fuentes (2009a). 
FRANCAMENTE 2.

\section{Operador argumentativo}

1. Este operador, originariamente enunciativo, muestra una cualidad de manera ostensiva y la intensifica.

2. Se combina con adjetivos y adverbios, a los que intensifica. Los precede y forma grupo entonativo con ellos. Actúa como un operador mixto: al resaltar una cualidad y mostrar una aserción reflexiva, lo sitúa en una posición alta:

La comida fue excelente: consomé de gambas, risoteo de alcachofas, avellanas y cebolletas; un tierno venado y por último una tarta de limón francamente ligera (El Mundo-Vino, 3-3-2003)// La razón hay que buscarla en que, hoy en día, en el mundo occidental, se vive francamente bien en una comisaría (Reporter, 15-22/6/2003).

\section{ORIGEN}

Adverbio de modo con el valor de de manera franca, sincera.

\section{POSICIÓN. ENTONACIÓN}

Se integra en la oración y antecede al segmento afectado, sin pausas.

\section{COMPORTAMIENTO EN EL PLANO MODAL Y ENUNCIATIVO}

No pierde el valor enunciativo, con lo cual el hablante se muestra comprometido con esa evaluación, que aserta tras una reflexión detenida:

La tercera estrofa retoma el perfil negativo del discurso poético inaugural.Perfil negativo en tanto el poeta trabaja la materia lingüística para sugerir imágenes dislocadas que sofocan la comunicabilidad del sentido volviéndolo por lo menos enigmático cuando no francamente abstruso (Espéculo. Revista de estudios literarios, 6-2003).

\section{PLANO INFORMATIVO}

Como efecto, aparece enfatizada esa información.

\section{PLANO ARGUMENTATIVO}

Operador escalar, que sitúa el segmento afectado en una posición elevada. Actúa como un intensificador. Es la actividad del decir al servicio de la argumentación:

Asturias está francamente mal en comparación con otras provincias (La Ratonera, Revista asturiana de teatro, 1-2002).

TIPOS DE TEXTO

t-tex.// cul.// or_es.//. (Fuentes: 2009a, pág. 177). 
2.3. Tomamos ahora un conector, elemento más estudiado y aceptado dentro de la sintaxis del español ${ }^{10}:$ por otra parte. Es un elemento complejo, habitualmente considerado un enumerativo (en relación con por una parte), pero que tiene diversas funciones. Lo hemos clasificado como conector de adición. Suma dos informaciones, pertenecientes a dos enunciados o dos oraciones, y presenta empleos específicos: puede ser un aditivo sin más, un enumerativo, tras por una parte, o por un lado, o bien, en un uso más específico, un conector de digresión. De esta forma, la información que se añade no estaba en el plan primigenio del hablante, es una información marginal, que se introduce con una intención determinada, ya que la considera rentable para lo que está tratando, y no había pensado en principio en ella, o bien, lo que suele ser más frecuente, porque de este modo aporta un argumento importante que supone un giro en la orientación enunciativa del discurso, abre otra línea y provoca ciertas inferencias. Es una dimensión, pues, a la vez informativa y enunciativa. Este uso tiene condiciones sintácticas fijas de aparición: al final, generalmente, y frecuentemente en oraciones de relativo explicativas.

Tipológicamente, sin embargo, pertenece a los conectores de adición. Pero ¿cómo explicar su inclusión junto a además, o cercano a conjunciones como $y$ ? La definición es multidimensional: sintácticamente $y$ es una conjunción que relaciona palabras, sintagmas u oraciones, predominantemente. Además o por otra parte son conectores, tienen una distribución específica, entre pausas, con movilidad, y conectan enunciados. Ahora bien, a la adición o suma de informaciones, añaden unos valores que pueden ser argumentativos: el elemento es superior en la escala, incluso considerado excesivo (encima), se añade a un conjunto precedente, no esperado (además), o bien predomina lo informativo, y entonces centramos nuestra atención en marcar que la información añadida no pertenece a la misma línea informativa (aparte). Con por otra parte añadimos algo que pertenece a otro ámbito, que no estaba en el plan primigenio del texto, que no es lo más relevante en un primer momento o plan textual, pero en otra línea enunciativa hay una relación de coherencia, o relevancia. Esta conexión está en un segundo plano, lo que hace menos esperada su aparición, y, por tanto, más informativa. Es algo no premeditado, secundario, o presentado así, como estrategia argumentativa. Esto le lleva a poder usarse con un valor de abrir un nuevo movimiento argumentativo, de dar paso a inferencias que van en otro sentido o contradicen lo anterior. Una forma sutil de añadir un argumento importante, que invalida lo previo, aunque sin anularlo. Puede incluso ser una marca polifónica: el hablante se desdobla y se autocomenta o abre una nueva perspectiva en su discurso.

Si no incluyéramos en nuestro diccionario estos valores en el plano informativo, modal, enunciativo o argumentativo no podríamos ver todo su comportamiento, y, además, no podríamos explicarlo con rigor, sin meras apreciaciones subjetivas.

10 De hecho, la bibliografía sobre ellos es inmensa, están siendo estudiados en todas las lenguas, tenemos varios diccionarios de conectores realizados o en marcha, tanto sincrónicos como diacrónicos. Vid. Briz (2005), Santos Río (2003), el que dirige Martín Zorraquino en Zaragoza sobre partículas modales, o el de Diccionario histórico que dirige J. A. Pascual; cfr. Garcés (2008). 
La caracterización, pues, se completa poniendo en juego lo que proviene de todos estos ámbitos.

POR OTRA PARTE.

Conector

adición

1. Añade una información nueva, no directamente relacionada con lo anterior pero al mismo nivel.

2. Puede usarse:

a) como segundo elemento de una enumeración, tras por una parte o por un lado;

b) añadiendo una nueva información relacionada o no con lo anterior;

c) en digresiones:

Con respecto a la lengua española se observan en los últimos tiempos algunas circunstancias paradójicas. Por una parte sufre la agresión cotidiana de la ignorancia y de la negligencia, favorecida por la falta de políticas educativas serias, y amplificada por el mal uso que suele hacerse de ella en los medios de comunicación; por otra parte, hay un número considerable y siempre creciente de personas que se preocupan por su deterioro y que procuran hablarla con propiedad y precisión, según atestigua el éxito de un cierto número de libros que no habrían alcanzado una difusión tan amplia en un país ya sin remedio analfabeto (El País. Babelia 15-2-2003)// 'Y para hacer todo ello no creo partir de una situación desventajosa en lo personal y, por otra parte, el Instituto no es algo nuevo para mí, tengo buenos amigos que trabajan aquí y conozco las condiciones en las que desarrollan la labor en algunos de sus centros', apuntó (Faro de Vigo, 28-3-2001)// Figa-tova. Literalmente, higo blando. Dícese del hombre blandengue, apocado, nonada, enmadrado o dominado por las 'tietas', elemento estructural el matriarcado catalán creador de una multitud de 'figuestoves' (se puede traducir por cojón-blando). Repletos de toda clase de virtudes patrióticas, por otra parte (El Mundo, 31-3-1996).

3. Une enunciados, oraciones o incluso sintagmas. Es frecuente su combinación con $y$, y su aparición en oraciones de relativo explicativas. En estas funciona como marcador de un comentario digresivo o introductor de un argumento:

También el académico Gregorio Salvador dijo a este periódico que si el caso se trasladara a otro punto de España y se discriminara a niños que hablan vascuence en vez de castellano 'hubiese ocurrido una especie de catástrofe, un escándalo' que, por otra parte, y en el caso que ha tenido lugar en Vizcaya, no ha extrañado, a su juicio, porque 'nos tienen acostumbrados en ese pedazo de España a estas cosas' (ABC Electrónico, 8-9-1997)// Una pacifista norteamericana, Rachel Corey, 
de 23 años, murió ayer aplastada por una excavadora del ejército israelí en un campo de refugiados de Gaza, cuando trataba de impedir que los soldados destruyeran su casa (...) Por otra parte, Arafat limitó ayer los poderes del nuevo primer ministro palestino (El País, 17-3-2003).

\section{ORIGEN}

Sintagma nominal con preposición. Se mantiene como complemento circunstancial en otros contextos.

\section{COMBINATORIA}

Se puede combinar con conjunciones: $y$, pero, porque...

\section{POSICIÓN. ENTONACIÓN}

Aparece como inicial, intercalada o final. Generalmente se antepone, aunque puede aparecer al final, pospuesta.// Aparece entre pausas, formando grupo entonativo independiente.

\section{COMPORTAMIENTO EN EL PLANO MODAL Y ENUNCIATIVO}

Indica una intervención del locutor que altera el plan primigenio del texto, introduciendo algo no planeado en principio:

Goza del bienestar social por el que, a su vez, Navarra se coloca en el primer puesto: vivienda, empleo, sanidad, enseñanza. Una posición ideal, por otra parte, para volver la vista con más fuerza a los sectores situados en la cuneta del camino (Diario de Navarra, 11-1-2001).

\section{PLANO INFORMATIVO}

Las informaciones se presentan como no relacionadas, pero importantes o relevantes desde el punto de vista del hablante.

\section{PLANO ARGUMENTATIVO}

Se utiliza para introducir argumentos, o informaciones que pueden cambiar la orientación argumentativa del discurso:

Por parte del PSOE, Joaquín Leguina, secretario del área de cultura de la Ejecutiva socialista, dijo que es fácil imaginar' lo que ocurriría de invertir las circunstancias del caso que, por otra parte, 'es un episodio bastante significativo y triste-señaló- ya que los niños que hablan castellano lo hacen porque es su lengua materna y reprimir ésta es una barbaridad' (ABC Electrónico, 8-9-1997).

TIPOS DE TEXTO

t-tex.// colcu.//or_es.//

\section{VARIANTES}

Por otro lado, de otro lado, de otra parte (Fuentes: 2009a, págs. 274-275). 
2.4. En nuestro análisis también hemos encontrado relaciones nuevas. Esta es la ventaja de trabajar sobre corpus, que los elementos considerados nos presentan todas sus funciones, más allá de lo que nuestra conciencia lingüística, siempre limitada, nos dicta. Es el caso de más bien, y otras unidades pertenecientes al plano de la enunciación. Es un elemento que tiene usos como operador y alguno como conector. $\mathrm{Su}$ valor enunciativo lo lleva también a lo reformulativo. Es un operador que intenta mostrar una aproximación a la intención formulativa del hablante. Indica, pues, habla aproximativa, no exacta, algo que supone aceptar que la intención comunicativa del hablante no siempre se cumple con éxito, y, además, que no siempre lo que pretende el hablante es expresarse con total precisión. A veces el pensamiento no está bien delimitado, no existe el término adecuado a la noción que se quiere expresar, o contextualmente no es oportuno ser directo. Implica, pues, la intención del hablante, pero también el objetivo argumentativo. Puede llegar a usarse como medio atenuativo en situaciones en que hay que reducir el impacto negativo que un término puede tener en el oyente. Un mecanismo de cortesía, pues.

Pero como enunciativo que es, puede derivar al uso reformulativo, en este caso a la corrección. Esta es una constante que hemos descubierto, algo lógico, por otro lado, puesto que pertenecen al mismo ámbito: la enunciación.

\section{MÁS BIEN.}

\section{Operador enunciativo}

1. Marca la expresión más adecuada, la más cercana a la intención denominativa del hablante. No es el término preciso, pero sí el más cercano.

2. Puede usarse:

a) Como aproximativo:

Esto se traduce hoy en que la oposición sigue manteniendo, básicamente, una actitud más bien de barricada, de resistencia, una actitud de protesta pero con muy poca propuesta alternativa (Ultima hora, 1211-2004)// Él era bajito, más bien petisón, como su madre (Guambia 453, 27-3-2004).

b) Como correctivo, en contraposición a otros, con valor exclusivo. Y en este valor puede combinarse con pero, o sino: "No...Sino más bien"; o "Más bien A que B":

Esta cuarta fase en la obra de Amable Arias -denominada La Quimera por la doctora Carmen Alonso-Pimentel, la principal investigadora de la vida y la obra del pintor leonés - no fue crepuscular sino más bien la etapa de mayor libertad creativa, espíritu lúdico, imaginación y carácter positivo en su evolución como artista (El Diario Vasco, 23-1-2004).

c) También puede indicar preferencia. Modifica a un sintagma o palabra.

De algún modo estas dos frases resumen el espíritu de todo el diálogo, que acaba (más bien se corta) justamente ahí: en los límites 
del sentido (El País, Babelia, 22-3-2003)// Quizás de allí que muchos de los pasos que haya dado sean más bien gateos, según esgrime la primera cabeza de la jurisdicción capitalina, Juan Barreto, aunque lo diga con otras palabras (El Universal, 27-12-2004)// Otras grandes haraganes muy conocidos son la mayor parte de nuestros políticos, quienes en lugar de trabajar incansablemente para servir a la sociedad como correspondería a su cargo muy bien remunerado, se dedican más bien a discutir proyectos y acciones que nunca se cumplen honradamente y que benefician más a sus bolsillos que al pueblo que cada día está más pobre (Última hora, 12-11-2004).

Corrige algo explícito o implícito. Incluso puede aparecer entre intervenciones o en parentéticos.

\section{ORIGEN}

Sintagma adverbial.

\section{COMBINATORIA}

Puede aparecer con conjunciones: $y, o$, pero, sino...

\section{POSICIÓN. ENTONACIÓN}

Precede al elemento sobre el que recae.// Se integra en el grupo entonativo del elemento que modifica.

\section{COMPORTAMIENTO EN EL PLANO MODAL Y ENUNCIATIVO}

Marca claramente el acercamiento aproximativo a la intención comunicativa del hablante. Es responsabilidad del locutor. A veces con valor claramente correctivo. Otras, atenúa una aserción rotunda:

La sala, más bien el corredor, estuvo llena con público que apreció con entusiasmo las ejecuciones del artista (El Universal, 23-3-2004)// En general los gobiernos asturianos han sido más bien pusilánimes en la materia (La Voz de Asturias, 21-8-2004).

\section{PLANO ARGUMENTATIVO}

Como aproximativo, puede usarse con valor atenuativo, quitándole fuerza a un término que puede resultar una evaluación fuerte, negativa o inadecuada. Actuaría dentro de la cortesía lingüística:

- Así que de Carlitos, de Gardel, nada de nada, ¿eh? -Francamente, más bien no (El Diario Vasco, 23-1-2004)// Se considera, que estaría por demás interpretar las diferentes muestras en detalle, siendo más bien importante el recalcar que los diseños dieron muy buenos resultados (Trama. Revista de Arquitectura y Diseño 86, 1-4-2004).

\section{TIPOS DE TEXTO}

t-tex.// colcu.// or_es.//. 


\section{VARIANTES}

Tiene el mismo valor de mejor, mejor dicho (Fuentes: 2009a, págs. 207-208).

La existencia de este operador constituye la gramaticalización de una relación, que por ello debe ser tenida en cuenta dentro del sistema y trasciende su propio paradigma. Implica la existencia de una enunciación imprecisa, de un tipo de contenido semántico, aproximativo o "borroso", "vago", como algunos autores han afirmado (Channell 1985, 1994, Crystal-Davy 1975). Esto supone una nueva visión del significado léxico y de la propia definición del "significar". Al mismo tiempo, nos lleva a la necesidad de realizar un estudio completo del ámbito de la enunciación y su influencia en el discurso. No sólo la tenemos que tener en cuenta para un tipo de adverbio (Nolke, 1993, 2001, Fernández Bernárdez, 2002, Fernández, 1994, Fuentes, 2004) o ciertas subordinadas (Gutiérrez Ordóñez 1997), sino que afecta a conectores (reformulativos), a una relación sintáctica (aposición) o al significado de los elementos: significado aproximativo.

El enunciar de forma aproximada puede permitir al hablante introducir una metáfora (ámbito léxico-semántico), expresar titubeo o inseguridad (disponibilidad léxica, modalidad) o acercarse al oyente de forma atenuada no queriendo invadirlo o imponerse (argumentación-cortesía). Al mismo tiempo lo acerca a la corrección, a la rectificación, a la preferencia entre diversas denominaciones... Y lleva del operador (límite dentro del enunciado) a la conexión entre ellos. En este ámbito se une a la cuantificación, a la cortesía (atenuación) y a la metáfora, un significado no literal, y en cierto modo también aproximado.

2.5. Veamos ahora un operador modal no al uso, que nos va a permitir descubrir cómo los niveles son más dúctiles de lo que una visión estricta ha querido imponer. Dichoso es un adjetivo que, antepuesto al sustantivo, introduce una valoración negativa del hablante. Es un elemento que sin dejar de actuar dentro de un sintagma nominal, por su posición sintáctica, desplaza el valor del elemento de la mera designación (o atribución) a un campo más genérico: la modalidad, la expresión de la subjetividad del hablante, de su emoción, en este caso negativa. Es una muestra del doble funcionamiento de estos elementos, y una llamada de atención para ver la multidimensionalidad que existe en el discurso, donde los elementos a la vez que actúan microestructuralmente dentro de la oración, como adyacentes o modificadores de un sustantivo, tienen una función mucho más elevada, que afecta a todo el enunciado. Por otro lado, asistimos a un desplazamiento significativo desde el contenido semántico designativo al coordenativo ${ }^{11}$ : a la modalidad. Se convierte en un instrumento discursivo, macroestructural. Señala una dimensión general

11 Vid. C. Fuentes (1998 y 2006b). 
DICHOSO,A.

Operador

modal

1. Es un modificador que aporta una valoración negativa, una minusvaloración del elemento al que afecta, y cierto valor exclamativo.

2. Aparece generalmente antecediendo a un sustantivo con el que concuerda, e indica que es algo muy conocido y valorado negativamente. El hablante está harto o rechaza lo que implica lo dicho por ese segmento:

Por culpa de la dichosa amigdalitis llevaba dos semanas de retraso en la preparación y me costaba recuperar la forma (La Vanguardia, 30-6-1995)// Los estudiantes que entrarán este año por primera vez en las aulas universitarias dicen que la borrachera de la selectividad ha sido demasiado larga, que se han pasado todo el año del COU pensando en cómo aprobar la dichosa prueba (El País digital 515, 30-9-1997).

\section{ORIGEN}

Adjetivo calificativo que funciona como tal sobre todo en posición pospuesta.

\section{POSICIÓN. ENTONACIÓN}

Antecede al sustantivo afectado.// Se integra en su grupo fónico.

\section{COMPORTAMIENTO EN EL PLANO MODAL Y ENUNCIATIVO}

A veces tiene valor polifónico, retomando discursos previos que el hablante valora negativamente.

\section{PLANO INFORMATIVO}

Enfatiza informativamente el elemento afectado.

\section{PLANO ARGUMENTATIVO}

La valoración negativa supone cierta antiorientación del argumento.

\section{TIPOS DE TEXTO}

conv./ colo./ or_es... (Fuentes: 2009a, pág. 109).

Lo mismo encontramos en otros elementos como: maldito, puto, famoso... Estas unidades incluso transmiten una información acerca del estado de ánimo del hablante, de sus características psicológicas, o de su registro, excesivamente informal, incluso inadecuado.

En "maldito país" adopta valor negativo, y no tiene el contenido de que el país haya sido maldecido, sino que el hablante lo valora negativamente, o que en este momento está enfadado y lo muestra en su habla. El contenido negativo pasa de recaer sobre el objeto país, a indicar la valoración del hablante, o, aún más marginalmente, el estado de ánimo o el estilo de habla de este (puede ser una forma de 
empatizar con alguien que protesta). Así, en un enunciado como "Es lo que ocurre en este maldito país" no puede ser considerado sin más un enunciado aseverativo modalmente, porque hay una carga modal negativa, una emoción de rechazo o de crítica claramente marcada. Pero ¿cuál es la marca? No hay curva entonativa distinta, sólo el contenido del adjetivo y su posición. Sería una manifestación de la modalidad implícita de Bally (1965). Pero ¿esto ya es modalidad o no?

En estos casos es la simple posición de un elemento la que hace que adopte una función diferente y pase del plano oracional al argumentativo. Igualmente en:

Es un simple ayudante/ Es un ayudante simple.

Antepuesto, simple supone que el ser ayudante se sitúa en un nivel argumentativo como insuficiente. Incluso lo acompaña de una valoración modal negativa. En "es un auténtico fiasco", auténtico enfatiza el contenido de fiasco. Es un operador informativo. La posición del adjetivo, como demostramos en Fuentes (2006b) implica la desviación hacia las coordenadas discursivas: modalidad, enunciación, argumentación o información.

La expresión de todas estas relaciones discursivas exige muchas veces la creación de nuevas expresiones, que con el tiempo se lexicalizan y aparecen fosilizadas con el valor de la operación discursiva que realizan. Podemos llegar a tener estructuras que se gramaticalizan y que parten de un sintagma para actuar como meros operadores, en este caso argumentativos:

Para colmo, ha llegado tarde.

Para colmo sitúa lo dicho en un punto de la escala muy elevado y considerado excesivo por parte del hablante. Este afirma que llegar tarde es algo que supera lo que puede soportar. Es inadecuado, por lo tanto añade una valoración negativa, y una posición escalar elevada. Es excesivo argumentativamente.

También construcciones como en otro orden de cosas, en ese sentido, o lo que es lo mismo, que van acercándose al empleo como conector.

Todos estos elementos nos muestran cómo es posible integrar lo más puramente sintáctico con aspectos venidos del entorno: hablante, oyente, intención, tipo de texto, fin del mismo, argumentación. Asimismo, distinguimos el valor básico de la unidad y sus desplazamientos contextuales. Esto suele ir acompañado de diferencias sintácticas o entonativas: cambios de posición, aislamiento en grupo fónico, etc. Al mismo tiempo vemos cómo la argumentación y la información se unen a otras manifestaciones del hablante: la enunciación o la modalidad. El hablante se muestra en su discurso y adapta las unidades del sistema a sus objetivos comunicativos, a su intención, provocando desplazamientos, creando elementos nuevos, que, si no se describen según estas claves, difícilmente pueden ser explicados. 


\section{Nivel sintagma o relaciones sintácticas}

3.1. La trascendencia de hacer una Lingüística pragmática que dé entrada al contexto comunicativo, formalizado en las diversas estructuras o módulos avanzados, no se limita a la descripción del paradigma de unidades específicas de cada plano. No termina en un inventario de operadores modales, enunciativos, argumentativos o informativos. Ni siquiera en comprobar que en ellos se da una interrelación entre las informaciones provenientes de cada plano. Trasciende al nivel del sintagma y a la descripción de la sintaxis del enunciado. De esta manera debemos superar el marco oracional y darle cabida a otras funciones que ocupan la periferia, que modifican a toda la oración y que extienden la sintaxis en otra dirección. Ya Gutiérrez Ordóñez se acercó a algunos de ellos en un artículo básico: "La determinación de los niveles oracionales" (1997). Nosotros los estudiamos en Fuentes (2005b y 2007a) ${ }^{12}$. Con ello nos situamos "beyond the sentence", algo normal en otros gramáticos no españoles ${ }^{13}$.

Al realizar el estudio sintáctico desde una perspectiva pragmática descubrimos que la lengua dispone de funciones correspondientes a cada plano macroestructural: enunciación, modalidad, información y argumentación. Cada uno de ellos se expresa mediante estructuras sintácticas que suelen aprovechar el margen izquierdo oracional, el inicio de la oración, colocándose entre pausas. La posición y la curva entonativa van a ser los manifestadores de este cambio sintáctico. La pausa cobra relieve como discriminador de funciones que hasta ahora no habían tenido cabida en la gramática.

Los estudios gramaticales ya han aceptado la existencia de adverbios de enunciación y de modalidad, como manifestaciones de estos niveles marginales. Es algo que no resulta traumático para el sistema, dado que el adverbio es la categoría menos estudiada tradicionalmente, donde había ido a parar todo aquello que no desempeña una de las funciones básicas verbales. De igual modo, en los estudios sobre las oraciones subordinadas, empiezan a aparecer referencias a la enunciación. Así Lapesa (1978) sobre las causales de dicto, Santos Río (2000), o Gutiérrez Ordóñez $\left(1997,1998\right.$ y 2000), pero esto se aplica a muchas otras ${ }^{14}$. Kovacci (1992) recoge en su libro muchas subordinadas que actúan como "modificadores de modalidad": causales, concesivas, condicionales o finales.

Por nuestra parte, hemos aplicado el modelo de manera rigurosa, y hemos encontrado la visualización sintáctica de estas dimensiones, creando todo un elenco de "complementos periféricos". En orden de marginalidad, pasaríamos de los cir-

12 El artículo es de 2005 aunque se publicó mucho más tarde, por problemas de edición.

13 Dik (1997) o Givón (1987, 1990). También Kovacci (1992) avanzó aspectos de este ámbito. Lombardi (1994, 1995, 1996, 1997, 2000) se centra en el aspecto informativo de la oración compuesta, Lehman (1988), G. Lakoff (1984), R. Lakoff (1984), Haiman-Thomson (eds. 1988), Tomlin (ed. 1987).

14 Cfr. Narbona (1989) en lo coloquial, y Gutiérrez Ordóñez (2000) y Montolío (1998) para las causales, Montolio $(1993,1999)$ condicionales, Marcovecchio (2002) para las concesivas...Vid. asimismo planteamientos generales en López García (1999 y 1994), Ramón Trives (1979, 1982, 2003), entre otros. 
cunstantes (Gutiérrez Ordóñez, 1997), los más cercanos al centro oracional, hasta los más externos: los complementos de modalidad o de enunciación. Entre ellos se sitúan los que pertenecen al ámbito de la información, concretamente el complemento tematizado, y la focalización. Esta última utiliza otros mecanismos aparte de la posición: entonación, pronunciación tensa, cambio de orden sintáctico... De esta manera encontramos que estos aspectos ligados al hablante (actitud subjetiva, conciencia del acto de hablar, o bien la disposición de la información de cara al oyente) se manifiestan no sólo en el orden sintáctico, la entonación, ... sino que incluso se visualizan y concretan en estructuras sintácticas que actúan como modificadores de lo expresado en toda la oración. Tienen un ámbito de actuación muy amplio. Ello supone la formalización más estricta de estos valores.

Los circunstantes son complementos que introducen una dimensión o una circunstancia temporal, local, causal, en la que se enmarca el hecho expresado en la oración. En la siguiente, como escritor es el ámbito en el que recae la pregunta sobre la responsabilidad del receptor:

Como escritor, ¿se considera con alguna responsabilidad moral con respecto a la sociedad? (Crea, ABC Electrónico, 17-10-1997).

En esta otra aparece una construcción absoluta de participio, estructura marginal que sitúa el marco temporal o causal:

Terminado el rodaje, Tato prefirió viajar hacia el Norte por razones particulares (Crea, Film [on line], 06-07-2003 ${ }^{15}$ ).

La diferencia con los complementos circunstanciales o aditamentos está en su marginalidad. Afectan a todo lo dicho, sea una oración o varias. Presenta una nueva predicación, y es toda ella la que actúa como marco en el que situar y cobrar relevancia el otro hecho.

Ambos circunstantes ocupan la posición antepuesta, pero también la pospuesta con pausa genera una nueva estructura:

Sin embargo, nadie espera que Fujimori vuelva a su tierra natal en el futuro cercano... si es que alguna vez lo hace (Crea, El País, 12-07-2001).

La oración condicional afecta al hecho de volver, expresado por el verbo. Pero aparece tras una pausa larga. Si lo analizamos sin más como una condicional, no damos cuenta de la intención del hablante. Este ha pretendido decir que nadie espera que Fujimori vuelva inmediatamente, pero después de haber llegado esta

15 "Terminado el rodaje" corresponde a las estructuras con función incidental, siguiendo la terminología usada por Martínez (1994) y Fernández Fernández (1993). 
información al receptor, se corrige e introduce una restricción: la condicional si es que alguna vez lo hace lo sitúa en un marco hipotético irreal, con lo cual la conclusión a la que llega el oyente es que no va a volver nunca. La primera información pierde relevancia, ya que limitar esa negación de la vuelta a un momento concreto queda sin operatividad al sugerirse la posibilidad de que nunca se realice. Hay dos informaciones que sin la pausa no aparecerían. De nuevo el hablante adquiere dos roles, crea un doble mensaje, enriquece la comunicación, adaptándola, en suma, a su subjetividad, su intención, su inteligencia, sus necesidades.

Es una reinterpretación. El hablante vuelve sobre lo dicho e introduce una nueva interpretación que no anula la anterior, sino que se añade a ella ${ }^{16}$, y cambia la orientación argumentativa de lo dicho. Por otra parte, no carga de responsabilidad al locutor, ya que al plantearse como una posibilidad o condición, el grado de aserción se rebaja, pierde fuerza, y por tanto, responsabilidad del hablante.

Si siguiéramos analizándolo como una oración condicional, no podríamos explicar estos matices, ya que las dos posibles interpretaciones serían:

$$
\text { si alguna vez lo hace: } \begin{aligned}
& \rightarrow \text { nadie espera } \\
& \rightarrow \text { vuelve a su tierra }
\end{aligned}
$$

Otra consecuencia inmediata es que no podemos identificar la forma con la función. No toda estructura "si+ oración" es condicional del verbo. Ahora bien, tampoco podemos caer en el análisis que antes criticamos en que se separaba la gramática de la pragmática. Es decir, defender que la estructura "si es que+ oración", gramaticalmente condicional, tiene como uso pragmático la negación de lo precedente o expresar una duda. Esto significaría que no podemos explicarlo gramaticalmente, sino pragmáticamente. Nosotros no estamos de acuerdo con esa separación. Evidentemente la interpretación que hemos hecho es correcta, pero tiene que trascender a la sintaxis. ¿Gramaticalmente cómo analizamos esta oración? ¿Es una condicional? ¿De quién? ¿Por qué la pausa? ¿Forman un solo enunciado? Estamos ante una relación nueva, que pertenece al plano enunciativo, la reinterpretación, que utiliza como molde sintáctico la posposición, tras pausa. Es un tipo de complemento periférico, o un nuevo enunciado, según los casos. De nuevo eso actúa como argumento que demuestra la existencia de este ámbito, ya que está gramaticalizado en una estructura sintáctica, el plano más abstracto dentro de la lengua. Si a ello añadimos otros factores podemos explicar dicho valor:

si: condición $\rightarrow$ no aserción

es que: focalización informativa del proceso

posición: la condición aparece después, no antes, con lo cual es necesario volver a interpretar el proceso.

16 Lo hemos tratado en Fuentes (2006a). 
Igualmente, en el campo de la enunciación hay muchas estructuras sintácticas: el adverbio o complemento de enunciación, tal como han apuntado algunos autores (Récanati, 1979; Fernández, 1994; Nolke, 1992, 2001; Nyan, 1998; Fernández Bernárdez, 2002; García Negroni-Tordesillas, 2001; Fuentes, 2004):

Con franqueza, creo que jamás has querido a nadie, ni siquiera a Serena (Crea, Salisachs, Mercedes: La gangrena, Planeta, Barcelona, 1976).

O la subordinada de la enunciación:

Para que lo sepas, aspiro a ordenar la sabiduría del pasado (Crea, T. Moix: El arpista ciego, Barcelona, Planeta, 2002).

Con franqueza no es un complemento de creo, sino del verbo decir subyacente a todo enunciado: "Yo digo con franqueza que creo..." Aparece al inicio, con pausas. En el segundo enunciado para que lo sepas es una final de la enunciación. Estas oraciones plantean un problema a la sintaxis, para ver cuál es el nivel de inserción o incidencia. ¿A quién modifican? ¿Son subordinadas? No se trata de esto ahora, son relaciones diferentes. Pertenecen a los complementos periféricos, que envuelven la oración y marcan estos niveles marginales del enunciado, señalando dimensiones o planos diferentes. En este caso, la intervención del hablante como enunciador.

Esta intervención, muestra de la actividad del sujeto hablante, tiene también una trascendencia en el plano informativo y argumentativo. Por una parte, sirve como mecanismo enfatizador de la información que sigue, al realizar el hablante esta reflexividad del texto, esta vuelta o mirada sobre el mismo. Y también le proporciona fuerza a la aserción, lo plantea como un argumento en posición elevada en la escala argumentativa. Puede usarse como una final de la enunciación con un valor de imposición.

La misma diversidad y polifuncionalidad encontramos en los enunciados que aparecen entre paréntesis. Es este otro esquema sintáctico supraoracional en el que dos enunciados se relacionan interrumpiéndose el uno al otro. ¿Por qué razón? Es otra muestra de una relación enunciativa: el hablante quiere mostrar la no planificación de esta inserción, a la vez que su relevancia: es una información necesaria, que el hablante debe conocer pero que suele ir en otra línea del texto. El hablante se convierte en un doble enunciador: uno que emite un mensaje, y es corregido por un alter ego que abre una línea argumentativa diferente. Generalmente quiere provocar ciertas inferencias que añadan contenidos, a veces antiorientados con lo anterior. Hacen llegar a conclusiones contrarias o cargan de contenido y doble sentido el enunciado.

Dice superVázquez que hemos manipulado al Papa. A mí que me registren: no tengo nada contra los Papas (muchos de mis mejores amigos son Papas), pero no me atraen tanto como para andar manipulándolos (Público, 6-5-2009, 8). 
En este caso muchos de mis mejores amigos son Papas aparece como un argumento del decir, una justificación.

Todo esto nos refleja realidades que necesitan una respuesta. En primer lugar, que la existencia de una pausa condiciona la interpretación del enunciado porque refleja intenciones comunicativas diferentes. En segundo lugar, esto tiene una trascendencia sintáctica: genera dos enunciados. Y entre ellos crea una relación enunciativa o argumentativa.

Otra estructura enunciativa es el complemento locutivo o de aserción, que nos aporta la fuente de información, ya sea el locutor o el enunciador.

Según varios testimonios, la familia que disparó contra los novios había intentado sin éxito impedir el enlace matrimonial en los días previos (Público, 6-5-2009, 14).

No podemos analizar según varios testimonios como un circunstancial de modo, ya que en absoluto indica esto. Por tanto, es necesario que consideremos la existencia de este tipo de complementos que indican la fuente del mensaje.

Aparte de ello, el indicar quién asume lo dicho enfatiza la información, descarga de responsabilidad al locutor. Puede usarse de este modo como argumento de autoridad, o bien como un medio de expresar el escepticismo o la duda del hablante. Este puede usarlo para hacer inferir lo contrario: "según mi novio, habríamos quedado a las 8", "según el detenido, el arma no era suya". Por tanto, esta estructura implica:

a) extender la sintaxis al ámbito del enunciado, contemplando la existencia de complementos que afectan a todo él

b) comprobar cómo un elemento enunciativo puede tener efectos en la argumentación y también en la modalidad.

Por otra parte, podemos comprobar cómo el ámbito de la enunciación se extiende superando el complemento del decir tradicional. Así, podríamos decir que la enunciación se muestra:

- en el sintagma: creando una relación nueva: la aposición

- en la oración: un complemento de enunciación que afecta a toda ella

- creando conectores y relaciones entre enunciados, sintagmas o palabras: los reformulativos (explicativos, correctivos...: esto es, es decir, o sea, vamos...).

- como marca de polifonía: marcando el desdoble del hablante en locutor y enunciador (adverbios modales, o complemento locutivo y de la aserción)

- en la incrustación de un discurso en otro: estilo directo e indirecto. 
Necesitamos contar con un instrumento teórico que nos permita explicar estos enunciados y diferenciar "Para que lo sepas, aspiro a ordenar la sabiduría del pasado" de "Aspiro a ordenar la sabiduría del pasado para que lo sepas". Si no, nuestra sintaxis es inadecuada, no se adapta a lo que quiere expresar el hablante, no se adapta al contexto. La Lingüística pragmática, sin embargo, al contemplar en su modelo el plano enunciativo, modal, informativo y argumentativo, nos permite abrir la sintaxis a otras relaciones con el mismo rigor que estudiamos un sintagma.

Esta visión pragmática en la que tantos aspectos aparecen imbricados es lo que necesitamos para poder explicar un fragmento de texto como el siguiente:

Sin perjuicio de que, en efecto, sean tontos de remate, yo creo que es una respuesta vaticana aprendida de los políticos. Ellos nunca se equivocan: lo que pasa es que les tergiversan. Su acción de gobierno jamás es nefasta: lo que pasa es que no la comunican bien. A ellos nunca les pillan con las manos en la masa: se trata de un montaje, no es lo que parece, lo pueden explicar todo (cariño) (Público, 6-5-2009, 8).

Pertenece a un artículo de opinión. Todos entendemos el sentido de lo expresado, pero no siempre podemos justificarlo sintácticamente. En el primer enunciado hay un elemento modal reafirmativo, en efecto, que recae sobre una información que aparece en subjuntivo, sean tontos de remate. Esta forma verbal supone el distanciamiento del hablante, que no entra en su aserción, pero en efecto lo reafirma, con lo cual establece este doble juego, ese doble sentido, del enunciador cortés ( $\sin$ perjuicio de que sean tontos..., yo no lo sé, no lo afirmo), y el menos cortés, que sí lo afirma, cayendo en la valoración negativa intensificada por de remate. Pero a continuación aparece una serie de enunciados formados por oraciones yuxtapuestas cuyos contenidos no sólo se oponen, sino que no pueden ser sostenidos por el mismo hablante, ya que caerían en la contradicción.

La primera parte del enunciado niega lo que todo el mundo cree (se equivoca, acción de gobierno nefasta, las pillan con las manos en la masa, es lo que parece), la segunda expone lo asertado por los protagonistas (las tergiversan, no la comunican bien, es un montaje, lo pueden explicar todo). Y el narrador queda fuera de ambos bandos, o sugiere, deja entrever que se decanta por el primero. Esto se manifiesta a través de ciertos índices, bastante interesantes. El primer segmento se niega con jamás o nunca, revelando el discurso del enunciador (aquel a quien se critica), que retoma el hablante, pero del que se distancia. A esa negación sigue la justificación. Esto se marca con conectores como es que (propio de las excusas), lo que pasa es que (giro enunciativo y focalización), o una estructura no lexicalizada como se trata de, que introduce otra justificación. Va precedida de un catafórico: es una respuesta aprendida de los políticos y la reafirma el uso de un vocativo: cariño, que aparece entre paréntesis ${ }^{17}$. Es una expresión muy rica significativamente, llena de inferencias,

17 Este tiene un valor textual importante, como comentaremos después. 
que deja sus marcas sintácticas, aunque a un nivel más alto del estudiado normalmente. Si no introducimos en la explicación el concepto de polifonía, distintos enunciadores, etc, no podríamos explicar esto y fracasaría nuestra sintaxis.

Pero hay más. En nuestro modelo metodológico incluíamos también la dimensión superestructural, donde el tipo de textos secuencialmente hablando o la intertextualidad son fundamentales. El cariño que aparece entre paréntesis no es un vocativo de este texto. Es un enunciado parentético, marginal, añadido por el periodista para que reinterpretamos lo anterior, como lo que le diríamos a nuestra pareja para justificarnos ante un reproche negando lo evidente. Ha introducido un discurso oral, la conversación coloquial de pareja como un eco, otro texto que se imbrica en él, enriqueciendo el contenido y llevándonos a otras conclusiones: miente. Ridiculiza el discurso de estas personas, como excusas aprendidas, de dormitorio.

3.2. Otras estructuras que hay que comentar desde el punto de vista de la oración es el empleo de ciertas oraciones de relativo explicativas, que, más que introducir una explicación, aportan un añadido. Esto ocurre con oraciones con lo cual, que generalmente tienen como antecedente todo lo dicho en la oración anterior. Pero introducen un comentario. Y habría que plantearse si no se trata de una estructura propia, que podríamos llamar "oraciones de comentario". El hablante establece una valoración, o un añadido, que en el fondo es una información marginal, de segundo plano o segundo momento enunciativo ${ }^{18}$, aunque muchas veces es sólo una estrategia argumentativa: presentarlo como marginal para así llamar la atención sobre lo que se presenta como "más fresco", momentáneo, no pensado... Así la oración de relativo con donde siguiente, en la que Rajoy incluye una información que nada tiene que ver en principio con la línea argumentativa del texto, pero abre inferencias que dan paso a otros contenidos y a cierta invalidación de lo dicho por el otro. Le acompaña por cierto (marginalidad informativa) y claro, que reafirma y convoca otras voces, otros enunciadores: lo dicho es evidente, conocido y compartido por toda la comunidad. Rajoy no es el único que lo piensa, no es de su cosecha, está utilizando lo que todos creen. Estas oraciones de relativo ${ }^{19}$ llevan una información aparentemente marginal, pero añaden otra línea argumentativa, un argumento poderoso con respecto a lo anterior. El hablante sugiere, más que afirmar.

100Rajoy: Quisiera comenzar, para dejar claro alguna cosa, que en la primera pregunta que hice en el Parlamento hablé del IVA, la financiación autonómica, los cien euros, del cálculo de las pensiones... ¿Esto es fútbol para usted, no? Es la muestra de que no le dice la verdad a los españoles e incluso con un papel delante,

18 Necesitamos introducir para el estudio de las subordinadas la variante informativa de foregrounding/backgrounding, ya que resulta muy rentable para poder ver los diferentes niveles y comportamientos de estas estructuras (cfr. Tomlin, ed., 1987).

19 Cfr. Lombardi (1994), Moreno Cabrera (1999), Scarano (2002). 
como no se lo ha dicho en el caso de la resolución de Irak. Usted ha hablado ahora, entre otras cosas, del Ministerio de Fomento, lo cual resulta verdaderamente sorprendente porque nunca en la historia había sido reprobado su responsable en el Senado y había sido reprobado su responsable en el Parlamento de Cataluña, donde por cierto, usted gobierna, claro (Debate Zapatero-Rajoy, 3-3-2008, El País Digital 4-3-2009).

Sintácticamente nos surgen nuevos interrogantes: ¿Cómo considerar la oración de lo cual? ¿Es relativa? ¿Su antecedente es toda la oración? Pero entonces no podríamos hablar de oración adjetiva. ¿Es una yuxtapuesta, y lo cual sólo un fórico? Podría considerarse como una nueva oración que añade una información valorativa de lo anterior. Tendríamos que pensar en despojar de su valor como nexo a la expresión lo cual.

En el caso de donde...sí hay un antecedente claro y, por tanto, una estructura adjetiva. Ahora bien, aporta una información conocida. ¿Por qué ha querido decirla el hablante? En este caso es un argumento relevante, abre una línea argumentativa que no desarrolla, deja que el interlocutor elabore la conclusión. Dicha conclusión contrasta con lo anterior. Comienza afirmando que ha sido reprobado su representante en el Parlamento de Cataluña y a continuación añade que él gobierna allí. Por tanto, hace inferir: no debería ser reprobado allí. Establece, pues, un contrasentido, un desajuste, que nos lleva a la conclusión de "hasta los suyos lo reprueban, no tiene poder".

Claro añade un valor de reafirmación, de presentar algo evidente. Luego pone de manifiesto o enfatiza la relevancia o poco esperado de lo dicho antes, porque si no es habitual sería más grave el hecho. Aquí no parece estar tan claro el valor de "es evidente", sino quizás "es esperable, es lógico, es conocido por todos". De nuevo otra conclusión implícita: "como ustedes se someten a los nacionalistas, gobiernan". Siembra la duda sobre su proceder.

\section{Nivel discursivo o textual}

En el nivel más alto del análisis el tema que ha preocupado en Pragmática y Lingüística textual ha sido la tipología, hacer una clasificación que respete los criterios constitutivos, lingüísticos y de adecuación contextual, pero sobre todo se ha dirigido a describir la conversación, ámbito en el que la influencia de los factores del entorno es inmediata y clara, y, además, estaba falto de atención investigadora.

Por otra parte, en el plano más contextual la teoría que está alcanzando un gran desarrollo y que para muchos es el paradigma de la pragmática es la de la cortesía. Cortesía verbal o comunicativa, vista desde el producto linguiístico o desde una perspectiva etnocentrista o sociocultural ${ }^{20}$. Es el lugar de fricción entre socioprag-

20 Cfr., entre otros, Haverkate (1994), Brown-Levinson (1978), Bravo (ed., 2003,), Bravo (2005), Bravo-Briz (eds., 2004), Placencia-García (eds, 2007). Watts et al (eds., 2005), Spencer-Oatey (ed., 2000), y las publicaciones del programa EDICE (www.edice.org). 
máticos y pragmalingüistas, con clara victoria hasta ahora de los primeros. Sin embargo, como ya hemos explicado en otros lugares (Fuentes 2009b, c, d, e, f, 2010a y b, Fuentes-Alcaide 2008, 2009) hay que interrelacionar todos los aspectos que intervienen para poder entender una comunicación.

Vamos a centrarnos en una unidad lingüística y comprobaremos cómo el tipo de discurso y las circunstancias socioculturales influyen en la determinación de sus efectos de cortesía, incluso en su función lingüística. Veámoslo primero en un fragmento del debate Zapatero/Rajoy del 3 de marzo de 2008.

Rajoy: Le voy a leer algunas afirmaciones suyas que son muy ilustrativas. Fíjese lo que dijo usted: "Yo quiero que nuestros soldados puedan regresar cuanto antes, pero entiendo que debemos responsabilizarnos de lo que por su voluntad, señor Aznar, hemos contribuido a desencadenar. Si abandonamos Irak a su suerte, el desastre humano en ese país puede tener proporciones gigantescas".

Eso lo dijo usted en el Congreso de los Diputados en diciembre de 2003. Le voy a decir algo que es mucho más importante y que demuestra quién es usted. Después de retirar las tropas de Irak, usted me refiero a usted, el señor Zapatero aprobó la siguiente resolución en el Consejo de Seguridad de las Naciones Unidas.

Después de irse, pide a los Estados miembros y a las organizaciones internacionales y regionales que presten asistencia a la fuerza multinacional, en particular, con fuerzas militares. Es decir, usted después de irse, le pide a todos los países del mundo que manden fuerzas militares.

Pero mire, en cualquier caso, es usted el que por lo visto quiere volver a hablar de Irak. No quiere hablar de Afganistán, ni quiere hablar del Líbano, que es donde están los soldados españoles en este momento.

Zapatero: Con el apoyo de Naciones Unidas.

Rajoy: Sí, sí, sí. Y con el apoyo de Naciones Unidas también estaban en Irak. Esa es una de las grandes mentiras, de las grandes contradicciones suyas a lo largo de esta legislatura.

Zapatero: ¿Sigue apoyando la guerra de Irak? ¿Sigue apoyando la guerra de Irak? No, dígalo, dígalo. ¿Usted cree que fue una buena aventura? ¿Cree que fue una buena aventura? ¡Está defendiendo la guerra de Irak!

Rajoy: Es usted el que la ha apoyado en la ONU pidiendo que mandaran fuerzas militares.

Zapatero: Esto si que va a ser exclusiva mundial, señor Rajoy..jdecir que yo apoyaba la guerra de Irak después de las decisiones que hemos tomado!

Rajoy: En cualquier caso, señor Zapatero, usted mintió a los españoles porque usted apoyó en el Consejo de Seguridad el envío de fuerzas militares después de haberlas retirado para quedar bien internamente y porque creía que le daba votos y apoyos. Usted sí que utilizó el terrorismo y no otros (Debate Zapatero-Rajoy, 3-3-2008, El País Digital 4-3-2009).

Este discurso se caracteriza por el enfrentamiento. Los papeles comunicativos están fijados previamente: Zapatero, al ser el presidente en ese momento, tiene que 
defender su gestión y Rajoy ataca para conseguir vencerle en las urnas. Ambos intentan destruir la acción y el discurso del otro. La retórica interpersonal fija un tratamiento lingüístico de respeto (el uso estratégico de usted), pero, al mismo tiempo, es normal el ataque a la imagen del otro: las acusaciones de mentir, de manipular, de gestionar mal, de no cumplir las promesas, etc. Se utiliza frecuentemente la reiteración (después de irse... después de irse...)

Cada participante se dirige al otro interlocutor, pero fundamentalmente al público votante, que es su fin argumentativo: convencer al ciudadano para conseguir el voto. Y, así, encontramos desacuerdos como usted me refiero a usted, el señor Zapatero aprobó la siguiente resolución en el Consejo de Seguridad de las Naciones Unidas.

En este enfrentamiento entre ambos aparece en cualquier caso, un nexo considerado generalmente como un conector concesivo. Su valor sería recoger una serie de argumentos previos, suspender su acción y enunciar una conclusión diferente a la deducida de ellos. Sin embargo, su comportamiento es diferente:

a) En el primer ejemplo, lo que precede lleva a la siguiente conclusión: "usted quiso tropas en Irak después de irse. Usted no es claro con el tema de Irak". En cualquier caso introduciría una conclusión contraria a esta, le quitaría relevancia a ello y lo orientaría en otra dirección, pero en este caso lo que anuncia es: "usted quiere hablar de Irak y no de Afganistán".

No hay una conexión causal como en una concesiva. La conexión se desplaza al plano del decir, a la enunciación. Y supone un cambio de tema. La relevancia que se suspende no es del hecho, sino del acto de hablar: "no hablemos de ese tema, dejemos ese tema, cambiemos a otro más importante". Se combina con pero. Y parece indicar también un giro enunciativo, algo propio de la adversativa. Además, introduce una deducción. Eso es lo que marca por lo visto. Se utiliza, pues, como un elemento que provoca un giro enunciativo: paso a otro tema más importante.

b) En el segundo caso, en cualquier caso quiere decir "sea o no verdad lo que usted dice, lo que sí es verdad es lo que sigue". En cierto modo concede, admite la deducción de Zapatero, no la niega, lo que implica una aceptación de lo dicho por el otro. Pero de nuevo implica un giro enunciativo: deja en suspenso el tema de Irak y se centra en la acusación a Zapatero. Podríamos pensar en un empleo metadiscursivo, que lo acercaría a las adversativas. Es decir, frente a la concesiva, que es una conexión entre los hechos A y B, en el que A $\rightarrow$ no B, y se afirma B, suspendiendo una implicación causal, en la adversativa, la relación es información A+ información B. B es más importante informativamente. La focalización o perspectiva del hablante se sitúa en el segundo elemento. Es una relación de jerarquización informativa y de presencia del enunciador sobre el segundo elemento. El hablante crea un enfrentamiento polifónico entre lo emitido en la primera oración y la segunda y se decanta por la segunda. Por tanto, el uso metadiscursivo hace pasar la relación de concesiva a adversativa. 
En este segundo caso, el valor concesivo implica suspender la relevancia de lo anterior, lo que trae consecuencias para la imagen de Rajoy: no le importa el tema de Irak, le da la razón a Zapatero, admite su razonamiento. Pero hay que tener en cuenta factores contextuales externos: que en este debate lo importante era el tiempo. Ambos querían tratar todos los temas. Por ello, Rajoy lo que hace con en cualquier caso es, de nuevo, llevar la conversación al punto que más le interesa: la acusación de mentir. Lo usa como un adversativo. Ahora bien, hay que tener en cuenta que en nuestra conciencia lingüística lo consideramos un concesivo, por lo que podemos deducir una interpretación lesiva para la imagen de Rajoy: él admite la acusación y no le importa, pasa al otro tema. Por tanto, entran en juego los factores situacionales y el tipo de discurso, en el que lo privilegiado es el enfrentamiento y el orientar cada uno la conversación hacia el tema que le resulte más favorecedor. Pero se cruza con el valor codificado de las unidades, que opera (o puede operar) en la mente de los receptores.

Por el contrario, en la siguiente publicidad, su efecto es diferente:

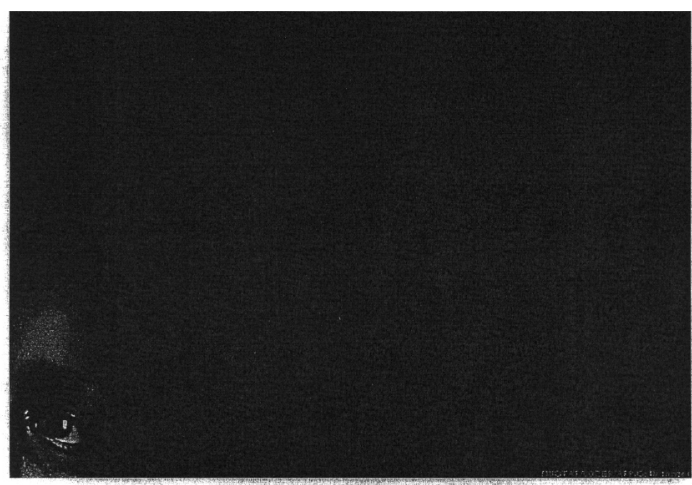

Hace 13 años, mientras el mundo miraba para otro lado, más del 800.000 personas fueron asesinadas en Ruanda.

En Darfur (Sudán) la violencia y la inseguridad se han cobrado ya cientos de miles de vidas y han obligado a desplazarse en los últimos ocho meses a 250.000 personas (algunas por tercera o cuarta vez). Darfur es otro triste ejemplo de que, a menos que seamos más fuertes, siempre habrá civiles cuyos derechos humanos no serán defendidos por nadie excepto tú y las personas que como tú no pueden permanecer impasibles ante estos abusos.

Necesitamos ser más para poder ayudarles. Y tú eres imprescindible en esta lucha pacifica.

Por eso te pido dos cosas urgentes: Firma esta petición para exigir al gobierno de Sudán que proteja a los civiles y coopere plenamente con el despliegue de tropas de paz aprobado por la ONU. Y considera hacerte socio ahora para que Amnistía Internacional pueda seguir dando voz a quienes nadie escucha.

En cualquier caso, gracias por estar a nuestro lado.

Esteban Beltrán 
Tenemos que tener en cuenta que el texto publicitario tiene un fin persuasivo predominante. En este caso conseguir convencer al receptor de que colabore con Amnistía Internacional. Por ello se describe una situación y a partir de ahí se pide la actuación del locutor: firmar la petición y hacerse socio. Es la conclusión que se deriva de lo anterior. Pero como lo que pide el hablante es un beneficio propio y un acto que supone un esfuerzo para ello, intenta convencer al oyente alabando su imagen. Utiliza la cortesía como un mecanismo argumentativo. Y para ello utiliza el movimiento concesivo que introduce en cualquier caso. Tras haber expuesto lo anterior, las peticiones, recoge todo ello y establece una contraargumentación: "hagas o no lo que te pido, te agradezco que estés a nuestro lado". Admite la posibilidad de no respuesta o no obedecer el mandato. Esto tiene un efecto positivo en el receptor, y quizás sea el argumento más persuasivo. El respeto a la imagen del otro, el tenerlo en cuenta por encima de todo es un arma para conseguir el beneficio.

Vemos, pues, cómo el conector concesivo en un texto adopta valor descortés, y en otro cortés. Es decir, el tipo de discurso, la situación comunicativa, social, la intención de los interlocutores actúa como un marco en el que los elementos se dirigen hacia el polo positivo o el polo negativo, hacia el respeto o el ataque a la imagen del otro.

Este tema de la cortesía es otra de las grandes líneas de investigación que se han puesto de moda ahora en Pragmática. Generalmente se aborda más desde el plano social pero es necesario, también aquí, la integración entre los aspectos etnográficos, socioculturales y los puramente lingüísticos. No puede obviarse el valor que las unidades llevan, ni el que el contexto o el tipo de discurso le aporta. Ya hemos comprobado en los ejemplos anteriores cómo el tipo de discurso tiene que ser una invariante que tener en cuenta, algo no reseñado generalmente ${ }^{21}$.

Podemos comprobarlo en otro fragmento del primer debate entre Zapatero y Rajoy (25-2-2008), en que se produce un enfrentamiento fuerte. Y veremos cómo lo que es formalmente descortés, se valora como menos fuerte por ser políticos los que hablan, y en un debate, próximo a las elecciones. Factores sociales o situacionales que hacen previsible, esperable el enfrentamiento, y, por tanto, reducen la descortesía. Hay que decir que es un efecto gradual, y que dependen de la interrelación de muchos componentes. Pero que haya determinaciones sociales, culturales, no implica que estos sean los únicos factores determinantes.

Z. Quiero hablar de futuro, del esfuerzo que este país tiene que hacer en materia de innovación y en materia de cultura. Mire, señor Rajoy, España sufre un retraso que estamos recuperando en materia de educación y ciencia. El Gobierno ha acompañado a los investigadores, a los creadores. Hace unos días, un conjunto de personas: investigadores, rectores, gente de la cultura, nombres tan representativos como Miquel Barceló, como Serrat, como Sabina, expresaron su apoyo a mi candidatura. Y usted les llamó "untados".

21 Vid. Fuentes (2009f). 
R. ¿Cómo?

Z. "Untados". A las personas de la cultura, de la investigación que habían salido apoyado mi candidatura. Señor Rajoy, un país que desprecia a sus profesores, a sus creadores, es un país que vuelve la espalda al futuro. Y un político que incurre en ese desprecio a la gente de la cultura y de la investigación no merece presidir un país.

R. Yo defiendo a los creadores, he sido ministro de Cultura, y defiendo a los artistas, pero a lo que no estoy dispuesto es a que me llamen, a diez millones de votantes, "turba de imbéciles" o de estúpidos. Eso no se puede hacer.

Yo lo que nunca haría sería agredir a las víctimas del terrorismo como lo ha hecho usted, porque eso sí que son personas indefensas, y no el señor Serrat y todos esos señores que ha citado usted.

$\mathbf{Z}$. Yo no he agredido a las víctimas del terrorismo.

R. Eso es lo que no haría yo...

Z. No, no, señor Rajoy, no se lo acepto. Es una acusación muy grave, yo no he agredido a ninguna víctima del terrorismo.

R. ...porque ustedes han estado en campaña constante contra las víctimas del terrorismo. Es igual que usted no me lo acepte, me trae completamente sin cuidado.

$\mathbf{Z}$. Pero es que yo no he agredido a ninguna víctima del terrorismo.

R. Yo mantengo lo que he dicho: que el señor Zapatero ha agredido a las víctimas del terrorismo. Lo mantengo, que quede claro. Lo que es evidente que yo no puedo aceptarle a una persona que pida el voto para usted que insulte a los demás, porque eso es inaceptable, se llame Serrat, o se llame como se llame. Hay que tener un poco de tolerancia y un poco de respeto a las personas y hay muchas personas que votan al Partido Popular, porque quieren y porque les apetece.

Ahora yo tengo que defender a la gente y usted tenía que haber defendido a las personas que fueron insultadas en el acto de los artistas. ¿Por qué no defendió a los insultados?

Z. Señor Rajoy, usted vinculó su declaración de "untados" al canon digital intentando hacer demagogia populista y descalificando a gente de la cultura...

R. Demagogia, la suya... (Debate Zapatero-Rajoy, 25-2-2008, El País Digital 26-2-2008).

El contexto es importante: Comienza con una acusación directa que hace Zapatero: "Y usted los llamó "untados"”. A partir de ahí pasa a la generalización, a la impersonalización, medios considerados atenuativos (Briz, 1998) porque desfocalizan el ataque, pasan de estar dirigido a Rajoy, a disfrazarlo en "Un país... un político...". Rajoy responde a esto con la acusación que los artistas les habían hecho: no estoy dispuesto (...) a que me llamen, a diez millones de votantes, "turba de imbéciles" o de estúpidos. Eso no se puede hacer. Pero luego pasa al ataque directo: Yo lo que nunca haría sería agredir a las víctimas del terrorismo como lo ha hecho usted, esto ya expresamente descortés. El tono es mucho más fuerte. A partir de aquí el enfrentamiento es cuerpo a cuerpo: No se lo acepto/ Es lo que no haría yo. Y ante esa negativa de Zapatero, Rajoy no la tiene en cuenta, y lo dice expresamente: Es igual 
que usted no me lo acepte, me trae completamente sin cuidado. Yo mantengo lo que he dicho: que el señor Zapatero ha agredido a las víctimas del terrorismo. Lo mantengo, que quede claro. $\mathrm{O}$ al final: Demagogia, la suya. Estas expresiones en sí son claramente descorteses, en un grado elevado. ¿Por qué no las percibimos así? Porque el contexto en el que se producen hace esperable el choque frontal, es su función como candidatos a las elecciones. Se relativiza por el contexto político. La pregunta ahora es: ¿para el ciudadano de a pie realmente pierden la violencia que las palabras llevan consigo? Yo diría que no, y es lo que los políticos no entienden. Se mueven en su propio código, en su propio entorno discursivo y sociocultural, pero no entienden que cuando se salen de la sala del Congreso, y los receptores son los ciudadanos, estos aplican su propio sistema, el general de la conversación, y de la conversación formal, donde expresiones como Demagogia la suya, (devolver la expresión del otro) suena a enfrentamiento sin recursos, pobre, excesivamente coloquial.

La teoría de la cortesía tiene que unir, como vemos, el valor que surge de las expresiones al contexto en que aparecen, pero debe tener en cuenta que en toda comunicación pueda haber varios subcódigos inmersos. En este caso el de los participantes en el debate y el de los receptores, que ellos parecen no haber tenido en cuenta. La percepción en unos y otros varía. Luego nuestro estudio pragmático sobre la cortesía necesita, de nuevo, una visión modular en la que todas las informaciones que provienen de los elementos lingüísticos y de los distintos factores del entorno interactúen para poder determinar la interpretación y sus efectos en el receptor.

\section{Conclusión}

Todo lo anterior nos muestra que es necesaria una propuesta modular de Lingüística Pragmática que sirva de modelo global para toda manifestación discursiva, en el nivel que sea. Necesitamos investigaciones que aborden los fenómenos desde una integración fructífera entre los elementos lingüísticos y el entorno (en toda su extensión), que formalicen las relaciones y demuestren que la gran diferencia con las propuestas inmanentistas anteriores radica en el enfoque multidimensional, sin el cual todo queda en una mera aproximación, no en un análisis riguroso. La Pragmática ya ha tenido desarrollo y es hora de disponer de una metodología clara y con poder explicativo. La que proponemos lo es, como hemos pretendido demostrar.

\section{Referencias bibliográficas}

Adam, J. M. (1990): Éléments de linguistique textuelle. Liège, Mardaga.

Alcaide, E., Ramos, Mª y F. J. Salguero (eds.) (1993): Estudios lingüísticos en torno a la palabra. Sevilla, Servicio de Publicaciones Universidad de Sevilla.

Alcaide, E., Brenes, E. y C. Fuentes (eds.) (2009): Actas del Congreso Internacional (Des) cortesía y violencia verbal en español, (en prensa). 
Álvarez Benito, G., Fernández Díaz, G. e I. Iñigo (eds.) (2009): International Conference on Political Discourse Strategies. Sevilla, Mergablum.

Anscombre, J. C. y O. Ducrot (1994): La argumentación en la lengua. Madrid, Gredos.

Austin, J. L. (1978): How to do things with words. London, Oxford Un. Press, $2^{\circ}$ ed.

Bally, Ch. (1965): Linguistique générale et linguistique française. Berne, Francke, $4^{\circ}$ ed.

Bosque, I. y V. Demonte (eds.) (1999): Gramática descriptiva de la lengua española. Madrid, Espasa.

Borrego, J., Fernández, J., Santos Río, L. y R. Senabre (eds.) (2000): Cuestiones de actualidad en lengua española. Salamanca/Bogotá, Universidad de Salamanca, I. Caro y Cuervo.

Bravo, D. (ed.) (2003): Actas del Primer Coloquio del Programa EDICE: 'La perspectiva no etnocentrista de la cortesía: identidad sociocultural de las comunidades hispanohablantes". Stockholms Universitet, www.primercoloquio.edice.org/actas/actas.htm

Bravo, D. (2005): "Categorías, tipologías y aplicaciones. Hacia una redefinición de la cortesía comunicativa”. En Bravo, D. (ed.): Estudios de la (des)cortesía en español. Categorías conceptuales y aplicaciones a corpora orales y escritos. Estocolmo-Buenos Aires, Dunken, págs. 21-52.

Bravo, D. y A. Briz (eds.) (2004): Pragmática sociocultural: estudios sobre el discurso de cortesía en español. Barcelona, Ariel.

Bravo, D. et alii (eds.) (2009): Aportes pragmáticos, sociopragmáticos y socioculturales a los estudios de cortesía en español. Buenos Aires, Dunken.

Briz, A. (1998): El español coloquial en la conversación. Barcelona, Ariel.

Briz, A. (2005): “Diccionario de partículas discursivas del español. Resultados de un proyecto de investigación”. En Martín Zorraquino, M. A. (ed.), en prensa. (www.dpde.com).

Brown, P. y S. C. Levinson ([1078]1987): Politeness. Some Universal in Language Use. Cambridge University Press.

Brugman, C. y M. Macauley (eds.) (1984): Proceedings of the Tenth Annual Meeting of the Berkeley Linguistics Society. Berkeley Linguistics Society.

Bustos, J.J. et alii (eds.) (1998): I Simposio Internacional de Análisis del Discurso. Madrid, Visor.

Casas Gómez, M. y R. Márquez (eds.) (2009): XI Jornadas de Lingüística. Cádiz, Universidad de Cádiz.

Casado, M., González, R. y M. V. Romero (eds.) (2006): Actas del I Simposio Internacional de Análisis del Discurso: lengua, cultura, valores. Madrid, Arco Libros Vol. II.

Channell, J. (1985): "Vagueness as a conversational strategy", Nottinghan Linguistic Circular, 14, págs. 3-24.

Channell, J. (1994): Vague Language. Oxford, Oxford University Press.

Crystal, D. y D. Davy (1975): Advanced conversational English. London, Longman.

Dik, S. C. (1997): The theory of functional grammar. 2: Complex and derived constructions, (ed. por K. Hengeveld). Berlin, Mouton de Gruyter.

Ducrot, O. (1984): El decir y lo dicho. Buenos Aires, Hachette Universidad.

Fernández, M. J.(1994): Les particules énonciatives dans la construction du discours. Paris, PUF. Fernández Bernárdez, C. (2002): Expresiones metalingüísticas con el verbo decir. La Coruña, Universidad de la Coruña.

Fernández Fernández, A. (1993): La función incidental en español. Oviedo, Dpto. Filología Española. 
Fuentes Rodríguez, C. (1987): Enlaces extraoracionales. Sevilla, Alfar.

Fuentes Rodríguez, C. (1993): “Conectores pragmáticos”. En Alcaide, E., Ramos, Mª y F. J. Salguero (eds.), págs. 71-104.

Fuentes Rodríguez, C. (1995): "Polifonía y argumentación: los adverbios de verdad, certeza, seguridad y evidencia en español”, Lexis XIX, 1, págs. 59-83.

Fuentes Rodríguez, C. (1996a): La sintaxis de los relacionantes supraoracionales. Madrid, Arco Libros (2a ed. 1998).

Fuentes Rodríguez, C. (1996b): Ejercicios de Sintaxis supraoracional. Madrid, Arco Libros, ( $2^{\mathrm{a}}$ ed. 1998).

Fuentes Rodríguez, C. (1997): “La Pragmática hoy en España. Su importancia en el análisis lingüístico”. En Fuentes (ed.), págs. 9-25.

Fuentes Rodríguez, C. (ed.) (1997): Introducción teórica a la pragmática lingüística. Sevilla, Kronos.

Fuentes Rodríguez, C. (1998): “Estructuras parentéticas”, LEA, XX/2, págs. 137-174.

Fuentes Rodríguez, C. (2000): Lingüística pragmática y análisis del discurso. Madrid, Arco Libros.

Fuentes Rodríguez, C. (2001): “Los marcadores del discurso, ¿una categoría gramatical?”. En Méndez, E., Mendoza, J. e Y. Congosto (eds.), págs. 323-348.

Fuentes Rodríguez, C. (2003): "Operador/conector, un criterio para la sintaxis discursiva", Rilce, 19,1, págs. 61-85.

Fuentes Rodríguez, C. (2004): “Enunciación, aserción y modalidad: tres clásicos”, Anuario de Estudios Filológicos, XXVII, págs. 121-145.

Fuentes Rodríguez, C. (2005a): "Partículas y modalidad". En Martín Zorraquino, M. A. (ed.), Zaragoza, en prensa.

Fuentes Rodríguez, C. (2005b): "Hacia una sintaxis del enunciado", Lingüística Española Actual, XVII/1, págs. 33-61.

Fuentes Rodríguez, C. (2006 a): “Eso sí y la reinterpretación enunciativa”, Oralia, 9, págs. 305-318.

Fuentes Rodríguez, C. (2006 b): “Un acercamiento pragmático a la posición del adjetivo”. En Casado, M., González, R. y M. V. Romero (eds.), págs. 1293-1309.

Fuentes Rodríguez, C. (2006c): “Operadores de intensificación del adjetivo: los cuantificadores escalares", Anuario de Estudios Filológicos, XXIX, págs. 35-53.

Fuentes Rodríguez, C. (2007a): Sintaxis del enunciado: los complementos periféricos. Madrid, Arco Libros.

Fuentes Rodríguez, C. (2007b): "El Diccionario de conectores y operadores del español”, Español Actual, 88, págs. 11-34.

Fuentes Rodríguez, C. (2008): “Operadores de intensificación del adjetivo: cantidad y evaluación”, Rilce, 24, págs. 1-24.

Fuentes Rodríguez, C. (2009a): Diccionario de conectores y operadores del español. Madrid, Arco Libros.

Fuentes Rodríguez, C. (2009b): "La argumentación en la lengua y la cortesía verbal, ¿dos teorías distintas?”. En Casas Gómez, M. y R. Márquez (eds.), págs. 109-148.

Fuentes Rodríguez, C. (2009c): "Parliamentary (im)politeness and argumentative force: "decirles, señorías, que...(to say, sirs, to you, that...)". En Álvarez Benito, G., Fernández Díaz, G. e I. Íñigo (eds.), págs. 63-80. 
Fuentes Rodríguez, C. (2009d): "Cuando la descortesía se convierte en agresividad: las listas de debate en el correo electrónico”. En Bravo, D. et alii, págs. 303-339.

Fuentes Rodríguez, C. (2009e): "Descortesía y agresividad bajo el anonimato: Internet". En Fuentes Rodríguez, C. y E. Alcaide Lara (eds.), págs. 190-212.

Fuentes Rodríguez, C. (2009f): “(Des)cortesía y violencia verbal: implicaciones linguiísticas y sociales”. En Alcaide, E., Brenes, E. y C. Fuentes (eds.), (en prensa).

Fuentes Rodríguez, C. (2010a): "La aserción parlamentaria: de la modalidad al metadiscurso", Oralia, 13, (en prensa).

Fuentes Rodríguez, C. (2010b): “Le voy a decir una cosa, pero no me diga usted...: el derecho a la palabra”. En Mariottini, L. (ed.), (en prensa).

Fuentes Rodríguez, C. y E. Alcaide Lara (2008): (Des)cortesía, agresividad y violencia verbal en la sociedad actual. Publicaciones Universidad Internacional de Andalucía.

Fuentes Rodríguez, C. y E. Alcaide Lara (eds.) (2009): Manifestaciones textuales de la descortesía y agresividad verbal en diversos ámbitos comunicativos. Publicaciones Universidad Internacional de Andalucía, en prensa.

Gallardo Paúls, B. (ed.) (1998): Temas de Lingüística y Gramática. Valencia. Universidad de Valencia.

Garcés, P. (ed.) (2008): Diccionario histórico: Nuevas perspectivas lingüísticas. Madrid, Iberoamericana.

García Negroni, M. y M. Tordesillas (2001): La enunciación en la lengua. Madrid, Gredos.

Gili Gaya, S. (1972): Curso superior de sintaxis española. Barcelona, Vox.

Givon, T. (1987): "Beyond foreground and background". En Tomlin, R. S. (ed.), págs. 175-188.

Givon, T. (1990): Syntax. Amsterdam, J. Benjamins.

Gutiérrez Ordóñez, S. (1997): “La determinación de los niveles oracionales”. En La oración y sus funciones. Madrid, Arco Libros, págs. 368-426.

Gutiérrez Ordóñez, S. (1998): “Oración compuesta y supuestos pragmáticos”. En Gallardo Paúls, B. (ed.), págs. 75-96.

Gutiérrez Ordóñez, S. (2000): “Causales”, BRAE, LXXX, págs. 47-159.

Haiman, J. y S. A. Thompson (ed.) (1988): Clause combining in grammar and discourse. Amsterdam, J. Benjamins P.C.

Haverkate, H. (1994): La cortesía verbal. Estudio pragmalingüístico. Madrid, Gredos.

Haverkate, H., Hengeveld, K. y G. Mulder (eds.) (1993): Aproximaciones pragmalingüísticas al español (Diálogos Hispánicos 12). Amsterdam y Atlanta, Rodopi.

Kovacci, O. (1992): El comentario grammatical. Madrid, Arco Libros.

Lakoff, G. (1984): "Performative subordinate clauses". En Brugman, C. y M. Macaulay (eds.), págs. 472-480.

Lakoff, R. (1984): “The pragmatics of subordination". En Brugman, C. y M. Macaulay (eds.), págs. 481-492.

Lapesa, R. (1975): "Sintaxis histórica del adjetivo calificativo no atributivo", Homenaje al Instituto de Filología y Literatura Hispánicas 'Dr. Amado Alonso' en su cincuentenario, Buenos Aires, págs. 171-199.

Lapesa, R. (1978): "Sobre dos tipos de subordinación causal”. Estudios ofrecidos a E. Alarcos Llorach, III, Oviedo, págs. 173-205.

Lehmann, C. (1988): “Towards a typology of clause linkage”. En Haiman, J.y S. A.Thompson (eds.), págs. 181-225. 
Lombardi Vallauri, E. (1994): “A multilevel functional classification of relative clauses", Linguisticae Investigationes, 18, 2, págs. 321-356.

Lombardi Vallauri, E. (1995): "A simple test for theme and rheme in the clause complex", Language Sciences, 17, 4, págs. 357-378.

Lombardi Vallauri, E. (1996): La sintassi dell'informazione. Roma, Bulzoni.

Lombardi Vallauri, E. (1997): "Relazione informative fra clausole nel parlato e nello scritto", Rassegna Italiana di Linguistica Applicata, 1, págs. 41-58.

Lombardi Vallauri,E.(2000): Grammatica funzionale delle avverbiali italiane. Roma, Carocci.

López García, A. (1999): "Relaciones paratácticas e hipotácticas”. En Bosque I. y V. Demonte (eds.), págs. 3507-3548.

López García, A. (1994): Gramática del español I. La oración compuesta. Madrid, Arco Libros.

Marcovecchio, A. M. (2002): “Concesivas oracionales: especificadores del valor veritativo, valorativas y metalingüísticas”, IV Congreso de Lingüística General, Área de Ling. General, Cádiz, págs. 1707-1715.

Mariottini, L. (ed.) (2010): Actas del IV Coloquio Internacional Programa EDICE, (en prensa).

Martín Zorraquino, M. A. y E. Montolío (eds.) (1998): Los marcadores del discurso. Teoría y análisis. Madrid, Arco Libros.

Martín Zorraquino, M. A. y J. Portolés (1999): "Los marcadores del discurso". En Bosque, I. y V. Demonte (eds.), págs. 4051-4213.

Martín Zorraquino, M. A. (ed.) (2005): Actas de las Jornadas sobre "El Análisis del discurso: partículas, modalidad y conexión”. Zaragoza, en prensa.

Martínez, J. A. (1994): "La función incidental y su conexión con otras construcciones del español”. En Cuestiones marginadas de gramática española. Madrid, Istmo, págs. 225283.

Méndez, E., Mendoza, J. e Y. Congosto (eds.) (2001): Indagaciones sobre la lengua. Estudios de Filología y Lingüística españolas en memoria de Emilio Alarcos. Sevilla, Universidad de Sevilla.

Montolío, E. (1993): “Si me lo permite...”. Gramática y pragmática: sobre algunas estructuras condicionales regulativas en español”, En Haverkate, H., Hengeveld, K. y G. Mulder (eds.), págs. 119-147.

Montolío, E. (1997): "La teoría de la relevancia y el estudio de los conectores discursivos". En Fuentes, C. (ed.) (1997), págs. 27-39.

Montolío, E. (1998): "Sobre el valor discursivo de la construcción causal [como A, B]”, En Bustos, J. J. et alii, (eds.) (1998), págs. 359-366.

Montolío, E. (1999): "Las construcciones condicionales". En Bosque, I. y V. Demonte (eds.), págs. 3643-3738.

Montolío, E. (2002): Conectores de la lengua escrita. Barcelona, Ariel.

Moreno Cabrera, J. C. (1999): "Las funciones informativas: las perífrasis de relativo y otras construcciones perifrásticas”. En Bosque, I. y V. Demonte (eds.), págs. 4245-4302.

Narbona, A. (1989): Sintaxis española: nuevos y viejos enfoques. Barcelona, Ariel.

Nolke, H. (1993): Le regard du locuteur. Paris, Kimé.

Nolke, H. (2001): Le regard du locuteur, II. Paris, Kimé.

Nyan, T. (1998): Metalinguistic Operators with reference to French. Berne, P. Lang. 
Placencia, M. E. y C. García (eds.) (2007): Research on Politeness in the Spanish-speaking World. Mahwah, L. Erlbaum.

Portolés, J. (1998): Marcadores del discurso. Barcelona, Ariel.

Ramón Trives, E. (1979): Aspectos de semántica lingüístico-textual. Madrid, Istmo-Alcalá.

Ramón Trives, E. (1982): Estudios sintáctico-semánticos del español I. La dinámica interoracional. Murcia, Godoy.

Ramón Trives, E. (2003): “Condición semántica de las palabras en relación con las modalidades paratácticas e hipotácticas de su puesta en discurso”, ELUA, 17, págs. 547-557.

Récanati, F. (1979): La transparence et l'énonciation. Paris, Seuil.

Roulet, E. (1991a): "Vers une approche modulaire de l'analyse du discours", Cahiers de Linguistique Française, 12, págs. 53-81.

Roulet, E. (1991b): "Une approche discursive de l'hétérogénéité discursive", Études de Linguistique Appliquée, 83, págs. 117-130.

Roulet, E. (1997): “A modular approach to discourse structures", Pragmatics, 7:2, págs. 125-146.

Roulet, E. (1998): “Un modèle et un instrument d'analyse de la complexité de l'organisation du discours". En Bustos, J. J. et alii, (eds.) (1998), págs. 133-158.

Santos Río, L. (2003): Diccionario de partículas. Salamanca, Luso-Española de Ediciones.

Santos Rio, L. (2000): "Rasgos, tipos y fronteras en la complementación respectual". En Borrego, J., Fernández, J., Santos Río, L. y R. Senabre (eds.), págs. 119-128.

Scarano, A. (2002): Frasi relative e pseudo-relative in italiano. Roma, Bulzoni.

Searle, J. (1980): Actos de habla. Madrid, Cátedra.

Spencer-Oatey, H. (ed. 2000): Culturally speaking: managing rapport through talk across cultures. London, Continuum.

Sperber, D. y D. Wilson (1986): Relevance. Communication and Cognition. Cambridge, Harvard U. P.

Tomlin, R. S. (ed.) (1987): Coherence and grounding in discourse, vol. 11. Amsterdam, J. Benjamins, P.C.

Watts, R. J. et alii (eds.) (2005): Politeness in Language, $2^{\text {nd }}$. Berlin, Mouton de Gruyter.

Zimmerman, K. (2003): "Constitución de la identidad y anticortesía verbal entre jóvenes masculinos hablantes de español”. En Bravo, D. (ed.) (2003), págs. 47-59, www.primercoloquio.edice.org/actas/actas.htm. 